\title{
WATER BUDGET AND SIMULATION OF ONE- \\ DIMENSIONAL UNSATURATED FLOW FOR A \\ FLOOD- AND A SPRINKLER-IRRIGATED FIELD \\ NEAR MILFORD, UTAH
}

By David D. Susong

\section{U.S. GEOLOGICAL SURVEY}

Water-Resources Investigations Report 95-4072

Prepared in cooperation with the

Utah Department of Natural Resources,

Division of Water Rights 


\section{U.S. DEPARTMENT OF THE INTERIOR \\ BRUCE BABBITT, Secretary \\ U.S. GEOLOGICAL SURVEY \\ Gordon P. Eaton, Director}

The use of trade, product, industry, or firm names is for descriptive purposes only and does not imply endorsement by the U.S. Government.

For additional information write to:

District Chief

U.S. Geological Survey

1745 West 1700 South

Room 1016 Administration Building

Salt Lake City, Utah 84104
Copies of this report can be purchased from:

U.S. Geological Survey

Earth Science Information Center

Open-File Reports Section

Box 25286, MS 517

Denver Federal Center

Denver, Colorado 80225 


\section{CONTENTS}

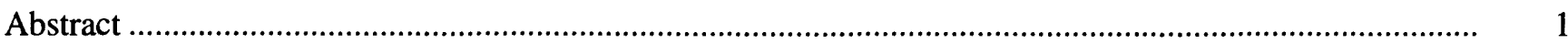

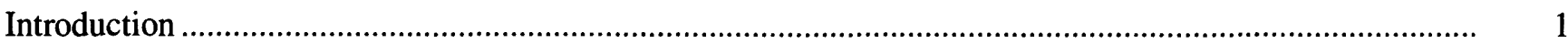

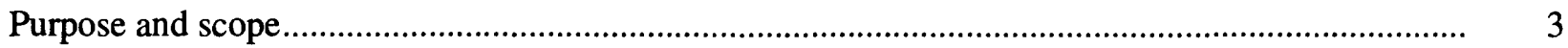

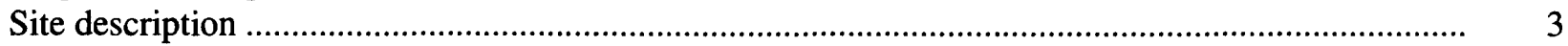

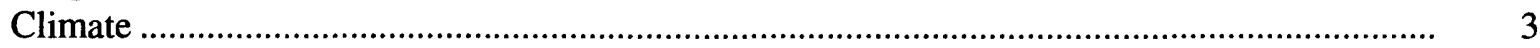

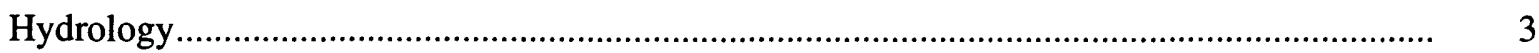

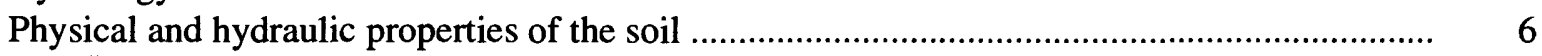

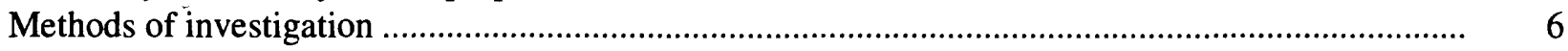

Water budget.

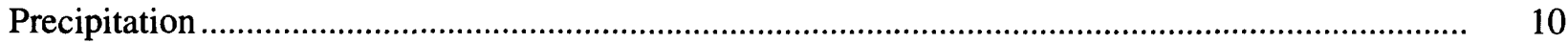

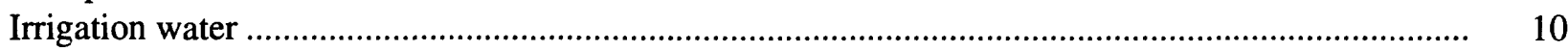

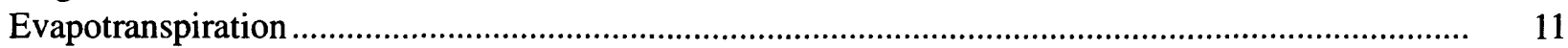

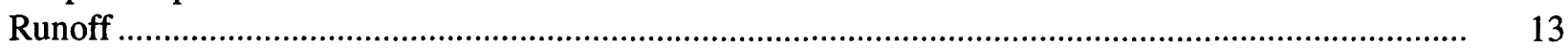

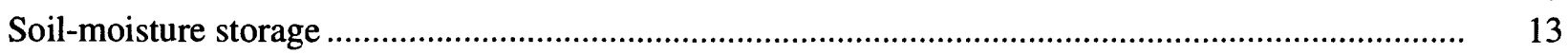

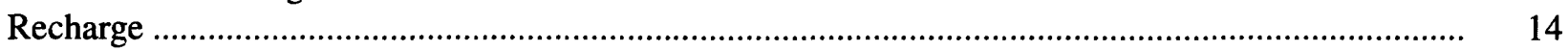

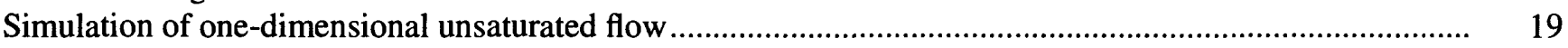

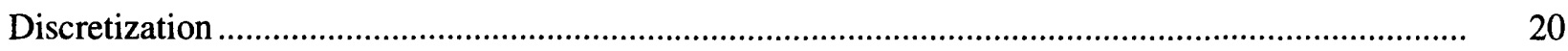

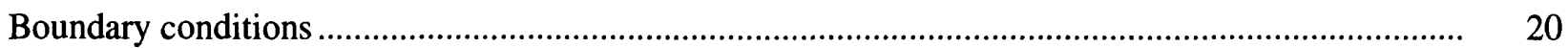

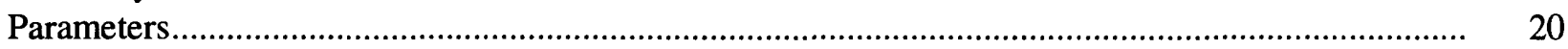

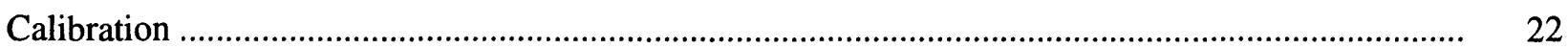

Simulated water budget for the flood- and the sprinkler-irrigated field for average climate conditions 26

Effects of distribution of flood-irrigation water on recharge .......................................................... 27

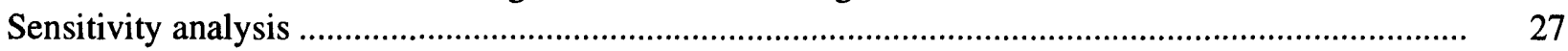

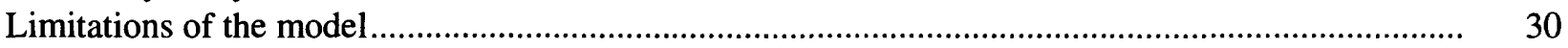

Summary

References cited

\section{FIGURES}

1. Schematic diagram and map showing location of study site, Milford area, Utah .......................... 2

2-15. Graphs showing:

2. Average hourly air temperature and wind velocity and daily precipitation and evapotranspiration at the study site, Milford area, Utah, 1992

3. Average hourly air temperature and wind velocity and daily precipitation and evapotranspiration at the study site, Milford area, Utah, 1993

4. Particle-size distribution of clod and core samples from the flood- and the sprinkler-irrigated field, Milford area, Utah

5. Relation of volumetric soil-moisture content with neutron-count ratio and capacitance probe Dcounts, flood-irrigated field, Milford area, Utah.

6. Application of irrigation water to the flood- and the sprinkler-irrigated field, Milford area, Utah, 1992 and 1993.

7. Relation between evapotranspiration data of the U.S. Geological Survey and Utah Climate Center, Milford area, Utah....

8. Volumetric soil-moisture profiles for the flood- and the sprinkler-irrigated field for the 1992 irrigation season and daily soil-moisture profiles for May 1993, Milford area, Utah.

9. Daily water content and change in daily water content in a soil column in the flood- and the sprinkler-irrigated field, Milford area, Utah, May and June, 1993.

10. Volumetric soil-moisture content at a depth of 1.52 meters in the flood-irrigated field, Milford area, Utah, 1993 


\section{FIGURES-Continued}

2-15. Graphs showing:-Continued

11. Water budget for the flood- and the sprinkler-irrigated field for 1992 and 1993 irrigation seasons, Milford area, Utah

12. Composite average particle-size distribution in soil clods from two pits and soil cores from four neutron-probe access holes in the flood- and the sprinkler-irrigated field, and unsaturated-flow-model textural classes and layers, Milford area, Utah

13. Simulated daily soil-moisture profiles in the flood- and the sprinkler-irrigated field for 1992 and 1993 irrigation seasons, Milford area, Utah

14. Simulated cumulative water budget for the flood- and the sprinkler-irrigated field for 1992 and 1993 irrigation seasons, Milford area, Utah

15. Simulated cumulative water budget for the flood- and the sprinkler-irrigated field for average climate conditions (1961-90) with 1992 and 1993 irrigation applications, Milford area, Utah .

16. Diagram showing simulated (a) uniform and (b) linear distribution of flood-irrigation water across a field

\section{TABLES}

1. Laboratory determined particle-size distribution, organic carbon content, and bulk density of soil in the flood- and the sprinkler-irrigated field, Milford area, Utah.

2. Summary of estimated and simulated water budget for the flood- and the sprinkler-irrigated field for the 1992 and 1993 irrigation seasons, Milford area, Utah

3. Simulated water budget for the flood- and the sprinkler-irrigated field for average climate conditions, Milford area, Utah

4. Water budget for three simulations that demonstrate the sensitivity of the model of the floodand the sprinkler-irrigated field to changes in saturated hydraulic conductivity, Milford area, Utah 


\begin{tabular}{|c|c|c|}
\hline Multiply & By & To obtain \\
\hline centimeter $(\mathrm{cm})$ & 0.3937 & inch (in.) \\
\hline centimeter per day (cm/day) & 0.03281 & foot per day (ft/day) \\
\hline cubic meter per minute $\left(\mathrm{m}^{3} / \mathrm{min}\right)$ & 0.1794 & cubic feet per minute $\left(\mathrm{ft}^{3} / \mathrm{min}\right)$ \\
\hline hectare (ha) & 2.471 & acre \\
\hline kilometer $(\mathbf{k m})$ & 0.6214 & mile (mi) \\
\hline meter $(\mathrm{m})$ & 3.281 & foot $(\mathrm{ft})$ \\
\hline meter per second $(\mathrm{m} / \mathrm{s})$ & 2.2369 & mile per hour $(\mathrm{mi} / \mathrm{h})$ \\
\hline millimeter $(\mathrm{mm})$ & 0.03937 & inch (in.) \\
\hline millimeter per day (mm/day) & 0.003281 & foot per day (ft/day) \\
\hline
\end{tabular}

Degrees Celsius $\left({ }^{\circ} \mathrm{C}\right)$ may be converted to degrees Fahrenheit $\left({ }^{\circ} \mathrm{F}\right)$ by using the following equation:

$$
{ }^{\circ} \mathrm{F}=9 / 5\left({ }^{\circ} \mathrm{C}\right)+32 \text {. }
$$

Sea level: In this report, "sea level" refers to the National Geodetic Vertical Datum of 1929-a geodetic datum derived from a general adjustment of the first-order level nets of both the United States and Canada, formerly called Sea Level Datum of 1929.

Dual units (metric and customary U.S.) are used throughout the text in this report to preserve the integrity of the original data, which were in metric form in the model, and at the same time present the data in a comprehensible form to the reader. 


\title{
WATER BUDGET AND SIMULATION OF ONE- DIMENSIONAL UNSATURATED FLOW IN A FLOOD- AND A SPRINKLER-IRRIGATED FIELD NEAR MILFORD, UTAH
}

\author{
By David D. Susong \\ U.S. Geological Survey
}

\section{ABSTRACT}

Ground-water recharge to basin-fill aquifers from unconsumed irrigation water in the western United States is being reduced as irrigators convert to more efficient irrigation systems. In some areas, these changes in irrigation methods may be contributing to ground-water-level declines and reducing the quantity of water available to downgradient users. The components of the water budget were measured or calculated for each field for the 1992 and 1993 irrigation seasons. Precipitation was about $6.5 \mathrm{~cm}$ ( 2.6 inches) both years. The floodirrigated field received 182 and 156 centimeters (71.6 and 61.4 inches) of irrigation water in 1992 and 1993, and the sprinkler-irrigated field received 52.8 and 87.2 centimeters ( 20.8 and 34.3 inches) of water, respectively. Evapotranspiration for alfalfa was calculated using the Penman-Monteith combination equation and was 95.4 and 84.3 centimeters (37.2 and 33.2 inches) for 1992 and 1993, respectively. No runoff and no significant change in soil moisture in storage was observed from either field. Recharge to the aquifer from the flood-irrigated field was 93.3 and 78.1 centimeters (36.7 and 30.7 inches) in 1992 and 1993 and from the sprinklerirrigated field was -35.9 and 9.3 centimeters $(-14.1$ and 3.7 inches), respectively. The daily water budget and soil-moisture profiles in the upper 6.4 meters ( 21 feet) of the unsaturated zone were simulated with an unsaturated flow model for average climate conditions. Simulated recharge was 57.4 and 50.5 percent of the quantity of irrigation water applied to the flood-irrigated field during 1992 and 1993, respectively, and was 8.7 and 13.8 percent of the quantity of irrigation water applied to the sprinkler-irrigated field.

\section{INTRODUCTION}

To reduce water use, irrigators in many areas of the western United States are changing irrigation methods to more water-efficient systems. In some areas, these changes in irrigation methods may be reducing the quantity of recharge to the ground-water system, thereby contributing to declines in ground-water levels and reducing the quantity of water available to downgradient users. Irrigation water is a major source of recharge to some basin-fill aquifers in the Basin and Range Physiographic Province (Fenneman, 1931), and the quantity of irrigation water that recharges the aquifers is a function of the method used to apply the water and the hydrogeologic characteristics and climate of each basin.

Irrigators in the western United States are converting from less efficient irrigation methods, such as flood irrigation, to more efficient sprinkler systems. Flood-irrigation methods include precision-leveled flood irrigation, furrow irrigation, and pulse irrigation. More efficient irrigation systems such as sprinkler systems reduce water use. In theory, ground-water withdrawals for irrigation likely would decrease as irrigation efficiency improves; however, irrigators also are increasing irrigated acreage as they improve irrigation efficiency by using water saved from improvements in efficiency to irrigate additional acreage. The improvements in efficiency combined with the increase in irrigated acreage might affect ground-water levels in basin-fill aquifers and the quantity of water available to downgradient users. To address this problem, the U.S. Geological Survey, in cooperation with the Utah Department of Natural Resources, Division of Water Rights, did a study in the Milford area of southwestern Utah (fig. 1) to quantify and compare the quantity of 

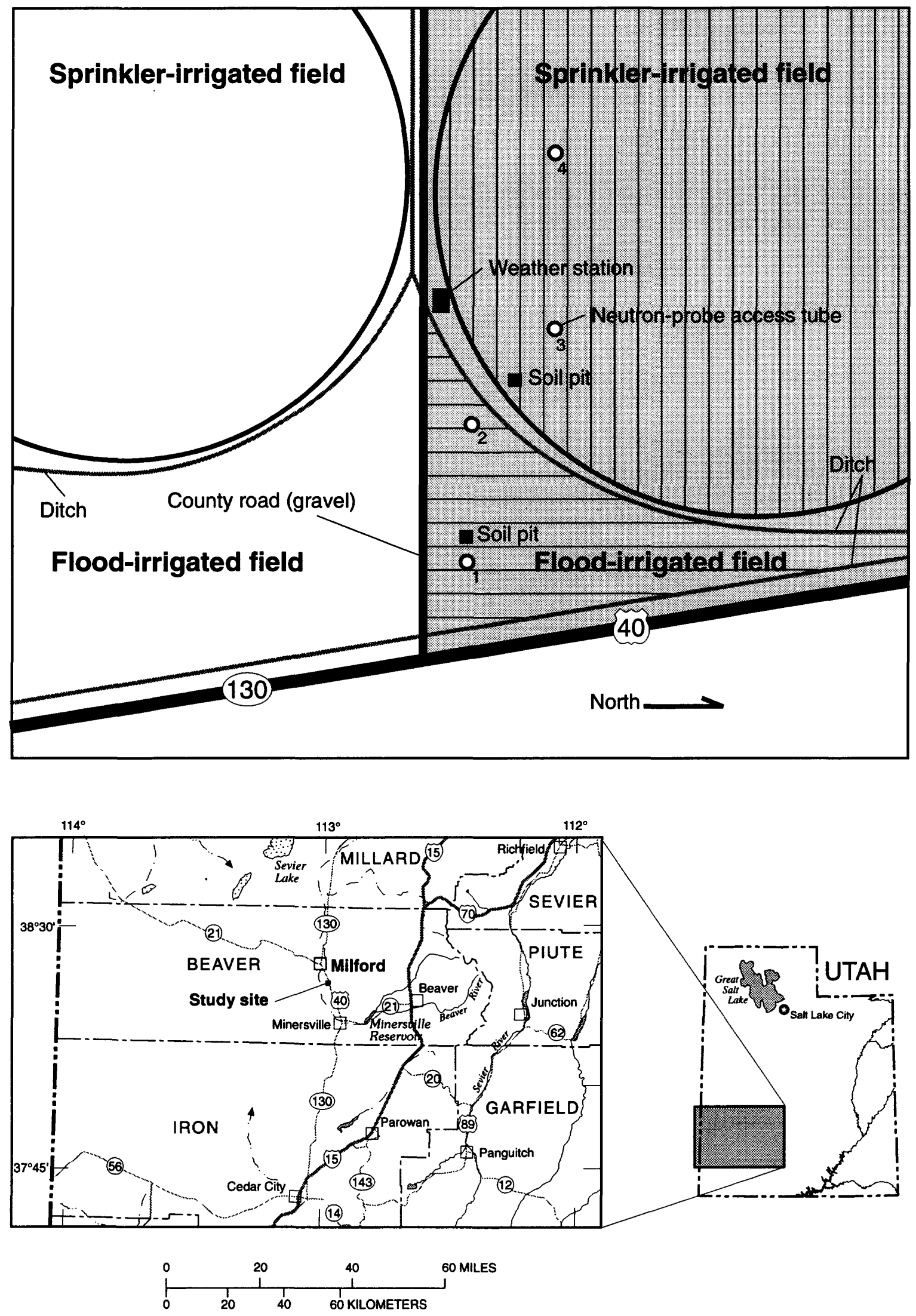

Figure 1. Schematic diagram and location of study site, Milford area, Utah. 
ground-water recharge occurring in a flood-irrigated field to that occurring in a sprinkler-irrigated field. Recharge is defined for the purposes of this study as water that infiltrates to a depth of at least $6.4 \mathrm{~m}$. This water also has been referred to as deep percolation in other studies and has the potential to infiltrate to the water table and recharge the basin-fill aquifer.

Location of irrigated fields in a basin also can affect the amount of recharge to the basin-fill aquifer and affect ground-water resources. If irrigated fields are located in recharge areas for basin-fill aquifers, then changes in irrigation methods that reduce recharge are likely to have a much greater effect on ground-water resources than if the fields are located in discharge areas.

\section{Purpose and scope}

This report describes the methods of investigation, water budget, and a one-dimensional unsaturatedflow model used to simulate ground-water recharge from irrigation water at a flood- and a sprinkler-irrigated field near Milford, Utah. The instrumentation and types of data collected are described in the following section of this introduction. Precipitation, irrigation water, evapotranspiration, runoff, soil-moisture storage, and recharge are discussed in the "Water budget" section of the report. The one-dimensional unsaturatedflow model and estimates of ground-water recharge from the application of the model to the two irrigated fields are presented in the "Simulation of one-dimensional unsaturated flow" section.

\section{Site description}

The Milford area is located in a basin of the Basin and Range Physiographic Province (Fenneman, 1931) in southwestern Utah (fig. 1). The altitude of the basin is about $1,525 \mathrm{~m}(5,004 \mathrm{ft})$, and the altitude of the highest point in the surrounding mountains is about $2,750 \mathrm{~m}$ $(9,023 \mathrm{ft})$. Irrigated agriculture is widespread in the central part of the basin. The study site is located between Minersville and Milford. The study site consists of two adjacent irrigated alfalfa fields: a 5.26-ha (13-acre) flood-irrigated field and a 32.4-ha (80-acre) center-pivot sprinkler-irrigated field (fig. 1).

The geology of the Milford area includes consolidated rocks of Precambrian to Tertiary age. The mountain ranges to the east and west of the area are composed mostly of igneous intrusive and volcanic rocks of Tertiary age: Coalescing alluvial fans extend from the mountains into the basin. The basin-fill deposits are reported in drillers' logs to be up to $261 \mathrm{~m} \mathrm{(856}$ ft) thick and consist of interbedded clay, silt, sand, and gravel (Mower and Cordova, 1974, p. 93). These deposits are alluvial, fluvial, and lacustrine sediments that are associated with Basin and Range faulting and mountain uplifts of Tertiary age and Lake Bonneville deposits of Pleistocene age.

\section{Climate}

The climate of the Milford area is characterized by moderate summer temperatures, cool winter temperatures, small amounts of precipitation, and moderate to strong winds. Average annual precipitation in the Milford area was $24.81 \mathrm{~cm}$ (9.8 in.) during 1960-90 (Robert Hill, Utah State University, written commun., 1994). An automated micrometeorology station was installed at the sturdy site. Average hourly air temperature and wind velocity and daily precipitation and evapotranspiration at the study site for April through September of 1992 and 1993 are shown in figures 2 and 3. Maximum average hourly air temperature for these periods was $35.0^{\circ} \mathrm{C}\left(95^{\circ} \mathrm{F}\right)$ and minimum was $-7.5^{\circ} \mathrm{C}\left(18.5^{\circ} \mathrm{F}\right)$. Maximum hourly wind velocity was $12.0 \mathrm{~m} / \mathrm{s}(27$ $\mathrm{mi} / \mathrm{h}$ ). Total precipitation for April 1 to September 15, 1992 , was $6.70 \mathrm{~cm}$ (2.64 in.) and for April 1 to September 30, 1993, was $6.40 \mathrm{~cm}$ (2.52 in.). Maximum daily evapotranspiration in April is a function of high wind velocities and warm temperatures. The maximum may be an overestimation of actual evapotranspiration because during high sustained wind velocities, plants compensate by closing stomata and increasing stomatal resistance. An alternative explanation of this high evapotranspiration value is that during high wind speeds, actual evapotranspiration exceeds potential evapotranspiration because of sensible heat advected from surrounding nonirrigated areas of the basin.

\section{Hydrology}

The Beaver River is the only major stream in the Milford area. The Beaver River enters the area near Minersville and flows north past Milford. Streamflow in the river is controlled by releases from Minersville Reservoir and by irrigation diversions. The river is often dewatered by irrigation diversions near Minersville. Ground water generally flows toward the center 

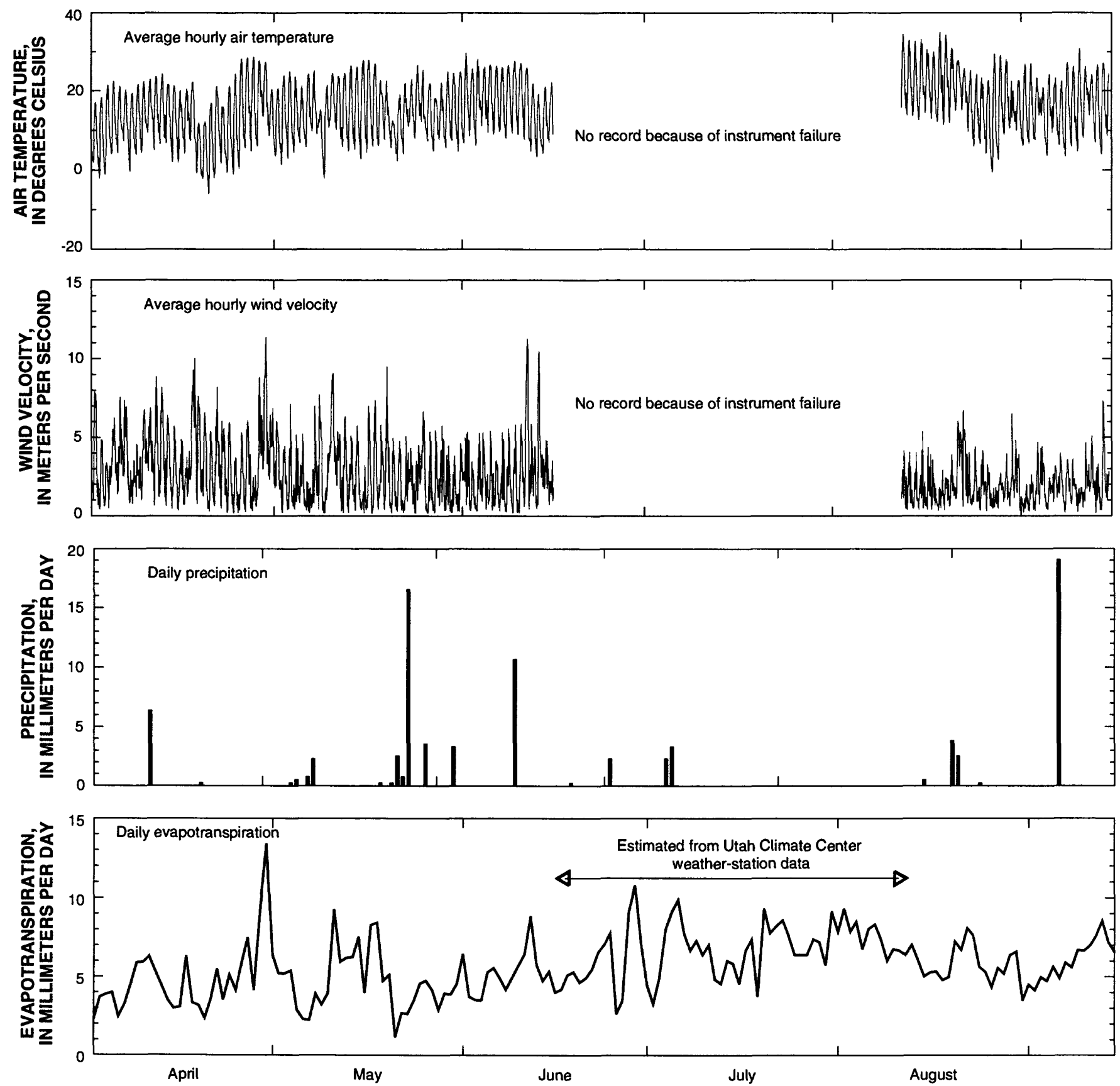

Figure 2. Average hourly air temperature and wind velocity and daily precipitation and evapotranspiration at the study site, Milford area, Utah, 1992. 

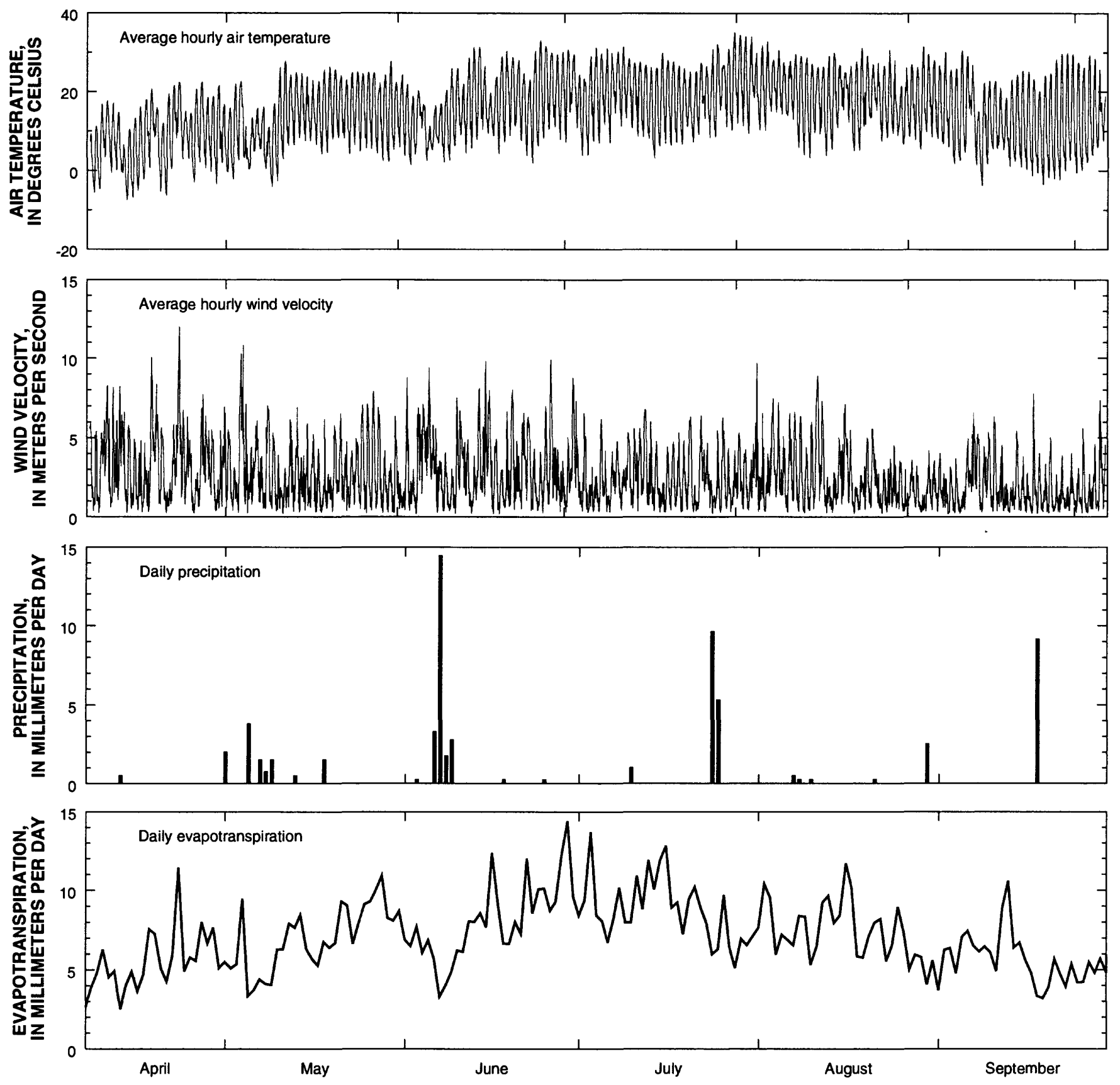

Figure 3. Average hourly air temperature and wind velocity and daily precipitation and evapotranspiration at the study site, Milford area, Utah, 1993. 
of the basin and exits the area to the north. The groundwater level near the study site in the basin-fill deposits is 15.3 to $36 \mathrm{~m} \mathrm{(50.2} \mathrm{to} 118 \mathrm{ft})$ below land surface and has been declining as a result of pumpage and drought. Ground-water movement at the study site is from east to west (Mower and Cordova, 1974, pl. 4).

\section{Physical and Hydraulic Properties of the Soil}

Soils at the study site are in the Taylors Flat series (Gordon Crandall, Soil Conservation Service, written commun., 1993). Based on particle-size distribution, the soil is generally classified as loam to clay loam. Soil samples were collected at two sites, one in each field. Clods were collected from soil pits (fig. 1) dug to a depth of $2.0 \mathrm{~m}(6.6 \mathrm{ft})$, and cores were collected from selected intervals from $2.0 \mathrm{~m}$ to $6.4 \mathrm{~m}$ (6.6 to $21.0 \mathrm{ft}$ ) deep in the neutron-probe access holes. Sample intervals for cores were selected to be representative of the major textural layers in the unsaturated zone. The clods and cores were analyzed for particle-size distribution, bulk density, saturated hydraulic conductivity, organic carbon, inorganic constituents, and moisture characteristics by the National Soil Laboratory of the Soil Conservation Service in Lincoln, Nebraska. Particle-size distribution, organic carbon content, and bulk density of samples from the two soil pits and the two adjacent neutron-probe access holes ( 1 and 3 ) and two additional neutron-probe access holes ( 2 and 4 ) are listed in table 1 . The intervals sampled with the clods and cores overlapped in the 124 to $152 \mathrm{~cm}$ (48.8 to $59.8 \mathrm{in}$.) interval (hole 1).

The particle-size distribution of clod samples collected from the soil pits and core samples collected from selected intervals in the adjacent neutron-probe access holes in the flood- and the sprinkler-irrigated field are shown in figure 4. The particle-size distribution indicates that the texture of the unsaturated zone is heterogeneous and layered and that the clay content varies from 6.2 to 58.7 percent, silt from 11.2 to 55.8 percent, and sand from 1.3 to 81.3 percent (table 1). The distinct layering of the unsaturated zone, such as the sandy layer beginning about $100 \mathrm{~cm}$ (39.4 in) below land surface and the clay and silt layer beginning about $200 \mathrm{~cm}$ (78.7 in.) below land surface (fig. 4), can influence the temporal and spatial movement of water through the unsaturated zone.

Saturated hydraulic-conductivity values for seven samples were determined by the National Soil Laboratory of the Soil Conservation Service and range from $0.21 \mathrm{~cm} /$ day $(0.0069 \mathrm{ft} /$ day $)$ to $21.6 \mathrm{~cm} /$ day $(0.71$ $\mathrm{ft} / \mathrm{day})$. The samples are from all four neutron-probe access holes and were selected to be representative of the major textures in the unsaturated zone. The depth interval of the samples and the saturated hydraulic-conductivity values are:

\begin{tabular}{rc}
\hline $\begin{array}{c}\text { Depth below } \\
\text { land surface, } \\
\text { in centimeters }\end{array}$ & $\begin{array}{c}\text { Saturated hydraulic } \\
\text { conductivity, } \\
\text { in centimeters per day }\end{array}$ \\
\hline 91 to 147 & 0.21 \\
91 to 155 & 7.5 \\
94 to 134 & 8.6 \\
359 to 368 & 7.8 \\
391 to 416 & 21.6 \\
396 to 490 & 6.9 \\
614 to 640 & 7.7 \\
\end{tabular}

The saturated hydraulic-conductivity values were less than expected when compared with values of soils of similar texture (Lappala and others, 1983; Rawls and others, 1982). The core samples were collected with a driven core sampler and may have been compacted or sheared during collection. The extraction of samples from the core-sample tubes also could have compacted or disturbed the samples.

Soil-moisture characteristic curves were developed for 10 samples from soil-moisture content measured at negative hydraulic heads of $-61 \mathrm{~cm}(-24 \mathrm{in}$.), $-102 \mathrm{~cm}$ (-40 in.), $-336 \mathrm{~cm}$ (-132 in.), $-1,020 \mathrm{~cm}(-402$ in.), and $-15,300 \mathrm{~cm}(-6,024$ in.). The curves were fit with van Genuchten's (1980) equation for relating negative hydraulic head and moisture content. The van Genuchten equation (Lappala and others, 1983) is used in the unsaturated-flow model and the coefficients determined in the curve fitting are required input for the unsaturated-flow model.

\section{Methods of Investigation}

The study site was instrumented to measure soil moisture and climate parameters. Much of the data was collected at 1- or 5-minute intervals and then averaged to hourly values. The measured parameters and their frequency of collection are listed at the beginning of page 9. 
Table 1. Laboratory determined particle-size distribution, organic carbon content, and bulk density of soil in the flood- and the sprinkler-irrigated field, Milford area, Utah

$\left[<\right.$, less than; $\mathrm{mm}$, millimeter; $\mathrm{g} / \mathrm{cm}^{3}$, grams per cubic centimeter; - , no data]

\begin{tabular}{|c|c|c|c|c|c|}
\hline $\begin{array}{l}\text { Depth below } \\
\text { land surface } \\
\text { (centimeters) }\end{array}$ & $\begin{array}{c}\text { Clay } \\
(<0.002 \mathrm{~mm}) \\
\text { (percent) }\end{array}$ & $\begin{array}{c}\text { Silt } \\
\begin{array}{c}(0.002 \text { to }<0.05 \mathrm{~mm}) \\
\text { (percent) }\end{array}\end{array}$ & $\begin{array}{c}\text { Sand } \\
\text { (0.05 to } 2 \mathrm{~mm}) \\
\text { (percent) }\end{array}$ & $\begin{array}{c}\text { Organic } \\
\text { carbon } \\
\text { (percent) }\end{array}$ & $\begin{array}{c}\text { Bulk density } \\
\text { (oven dry) } \\
\left(\mathrm{g} / \mathrm{cm}^{3}\right)\end{array}$ \\
\hline \multicolumn{6}{|c|}{ FLOOD-IRRIGATED FIELD } \\
\hline \multicolumn{6}{|c|}{ Soil pit } \\
\hline 0 to 5 & 20.3 & 52.4 & 27.3 & 0.96 & 1.54 \\
\hline 5 to 23 & 20.2 & 53.5 & 26.3 & .84 & 1.45 \\
\hline 23 to 36 & 23.0 & 51.0 & 26.0 & .71 & 1.44 \\
\hline 36 to 69 & 27.6 & 34.3 & 38.1 & .19 & 1.61 \\
\hline 69 to 97 & 27.4 & 37.8 & 34.8 & .4 & 1.55 \\
\hline 97 to 117 & 26.2 & 35.1 & 38.7 & .17 & 1.58 \\
\hline 117 to 152 & 18.2 & 17.9 & 63.9 & .09 & 1.61 \\
\hline \multicolumn{6}{|c|}{ Neutron-probe access hole 1} \\
\hline 124 to 172 & 11.3 & 17.7 & 71.0 & .05 & - \\
\hline 211 to 254 & 42.1 & 55.8 & 2.1 & .06 & 1.73 \\
\hline 284 to 345 & 23.6 & 24.8 & 51.6 & .08 & 1.87 \\
\hline 614 to 640 & 12.2 & 20.8 & 67.0 & .03 & - \\
\hline \multicolumn{6}{|c|}{ Neutron-probe access hole 2} \\
\hline 94 to 134 & 6.2 & 12.5 & 81.3 & .06 & - \\
\hline 185 to 223 & 58.2 & 40.5 & 1.3 & .1 & 1.33 \\
\hline 305 to 315 & 27.9 & 25.3 & 46.8 & .07 & - \\
\hline 359 to 368 & 24.8 & 25.0 & 50.2 & .20 & - \\
\hline \multicolumn{6}{|c|}{ SPRINKLER-IRRIGATED FIELD } \\
\hline \multicolumn{6}{|c|}{ Soil pit } \\
\hline 0 to 5 & 28.9 & 45.4 & 25.7 & 1.7 & 1.58 \\
\hline 5 to 25 & 29.9 & 47.4 & 22.7 & .63 & 1.60 \\
\hline 25 to 46 & 30.4 & 54.5 & 15.1 & .31 & 1.47 \\
\hline 46 to 61 & 27.4 & 49.9 & 22.7 & .34 & 1.47 \\
\hline 61 to 87 & 33.5 & 39.6 & 26.9 & .54 & 1.31 \\
\hline 87 to 152 & 12.0 & 11.2 & 76.8 & .08 & 1.51 \\
\hline \multicolumn{6}{|c|}{ Neutron-probe access hole 3} \\
\hline 213 to 274 & 58.7 & 37.8 & 3.5 & .12 & 1.85 \\
\hline 391 to 416 & 39.9 & 24.6 & 35.5 & .11 & - \\
\hline 548 to 564 & 39.3 & 36.6 & 24.1 & .13 & 1.45 \\
\hline \multicolumn{6}{|c|}{ Neutron-probe access hole 4} \\
\hline 97 to 147 & 17.5 & 23.8 & 58.7 & .20 & - \\
\hline 241 to 274 & 19.9 & 25.6 & 54.5 & .05 & - \\
\hline 396 to 490 & 21.0 & 32.6 & 46.4 & .16 & - \\
\hline 561 to 594 & 22.7 & 23.1 & 54.2 & .12 & - \\
\hline
\end{tabular}



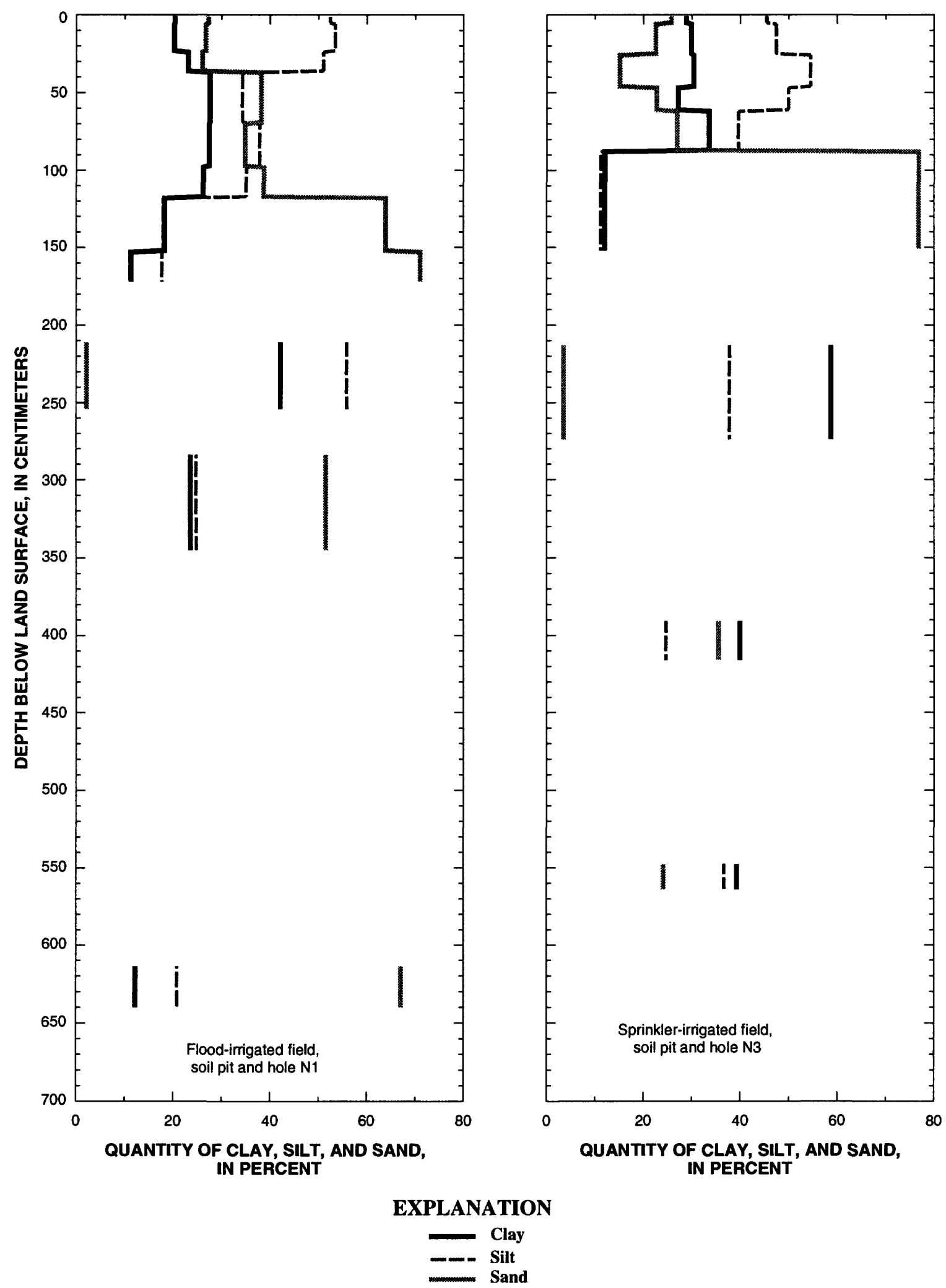

Figure 4. Particle-size distribution of clod and core samples from the flood- and the sprinkler-irrigated field, Milford area, Utah. 


\begin{tabular}{cc}
\hline Parameter & $\begin{array}{c}\text { Interval of } \\
\text { data collection }\end{array}$ \\
\hline
\end{tabular}

Soil moisture

Neutron probe

Approximately biweekly

during 1992, and daily

during May and part of

June, 1993

Capacitance probe 5 minute, averaged hourly

Air temperature

Soil temperature

Relative humidity

Heat flux of soil

Net radiation

Wind velocity

Wind direction

Hydraulic head of soil

Amount of applied irrigation water

Amount of runoff
1 minute, averaged hourly

1 minute, averaged hourly

1 minute, averaged hourly

1 minute, averaged hourly

1 minute, averaged hourly

1 minute, averaged hourly

1 minute, averaged hourly

hourly, intermittent record, 1992

periodically

No runoff observed during site visits

Soil moisture was measured with a soil-moisture neutron probe at four locations at the study site, including two locations in the flood-irrigated field and two locations in the sprinkler-irrigated field (fig. 1). Aluminum access tubes for the neutron probe were installed to a depth of $5.75 \mathrm{~m}(18.9 \mathrm{ft})$ or $6.4 \mathrm{~m}(21.0 \mathrm{ft})$, except for the access tube in the lower end of the flood-irrigated field, which was installed to a depth of $3.65 \mathrm{~m}$ $(12.0 \mathrm{ft})$. Cemented soil at a depth of $3.65 \mathrm{~m}$ (12.0 ft) could not be penetrated with the auger. Soil-moisture measurements were made with a soil-moisture neutron probe at about 2-week intervals in 1992 and daily for May and part of June in 1993. The soil-moisture measurements in 1993 were designed to track daily changes in soil moisture and would have continued the entire season had there not been problems with the neutron probe. The soil-moisture measurements were collected as neutron-count ratios. The neutron probe was calibrated using soil samples collected during installation of the access tubes and soil samples collected from holes augured near the access tubes periodically during the irrigation season. Soil cores were collected and moisture content was determined by the standard gravimetric method (Kramer, Cullen, and Everett, 1992). Neutron-probe measurements were made immediately following collection of the cores at the depths at which the samples were collected and $15 \mathrm{~cm}$ (5.9 in.) above and below the sample depth. These three neutron-probe

measurements were averaged and used to develop a linear regression curve with the gravimetric soil-moisture data. The regression curve and equation (fig. 5) have coefficient of determination (R-squared) of 0.86 and a $\mathrm{p}$ value less than $1 \times 10^{-4}$.

Soil moisture also was measured with capacitance probes connected to a data logger in the upper end of the flood-irrigated field. These probes were installed at depths of $1.52 \mathrm{~m}(5.0 \mathrm{ft}), 2.10 \mathrm{~m}(6.9 \mathrm{ft})$, and $3.65 \mathrm{~m}$ $(12.0 \mathrm{ft})$, recorded soil moisture at 5-minute intervals, and averaged the data hourly. These probes were used to monitor the movement and timing of water through the unsaturated zone. The capacitance probes were calibrated with the same method used for the neutronprobe calibration. The regression curve and equation (fig. 5) have an R-squared value of 0.80 and a $p$ value less than $1 \times 10^{-4}$. Numerous instrument problems in 1992 precluded the collection of any useable data. Data were collected with the capacitance probes for April to September in 1993 . The $2.10 \mathrm{~m}(6.9 \mathrm{ft})$ and $3.65 \mathrm{~m}$ (12.0 ft) probes are missing some record as a result of moisture penetrating the cable connections. The $1.52 \mathrm{~m}$ $(5.0 \mathrm{ft})$ probe has a complete set of data.

Climate parameters were measured with an automated weather station located between the flood- and the sprinkler-irrigated field (fig. 1). The weather station is surrounded by fields of irrigated alfalfa. The field to the south of the weather station was planted with alfalfa and oats in 1992. All the data were collected once each minute and were averaged hourly for April 1 to September 30, 1992, and April 1 to September 30, 1993. The weather station was vandalized in 1992 and was not operating from June 16 to August 12, 1992.

Regressed data from the Utah Climate Center Milford weather station was used to estimate the missing data. The set of 1993 climate data is complete with the exception of the data from the net radiometer, which was damaged for a short period. The missing data was obtained by interpolation.

\section{WATER BUDGET}

The components of the water budget for each field were either measured at intervals, or were calculated or estimated at the study site. Precipitation during the growing season was measured continuously with a tipping-bucket rain gage. Evapotranspiration was calculated hourly from climate parameters. The quantity of soil-moisture in storage was determined from soil- 

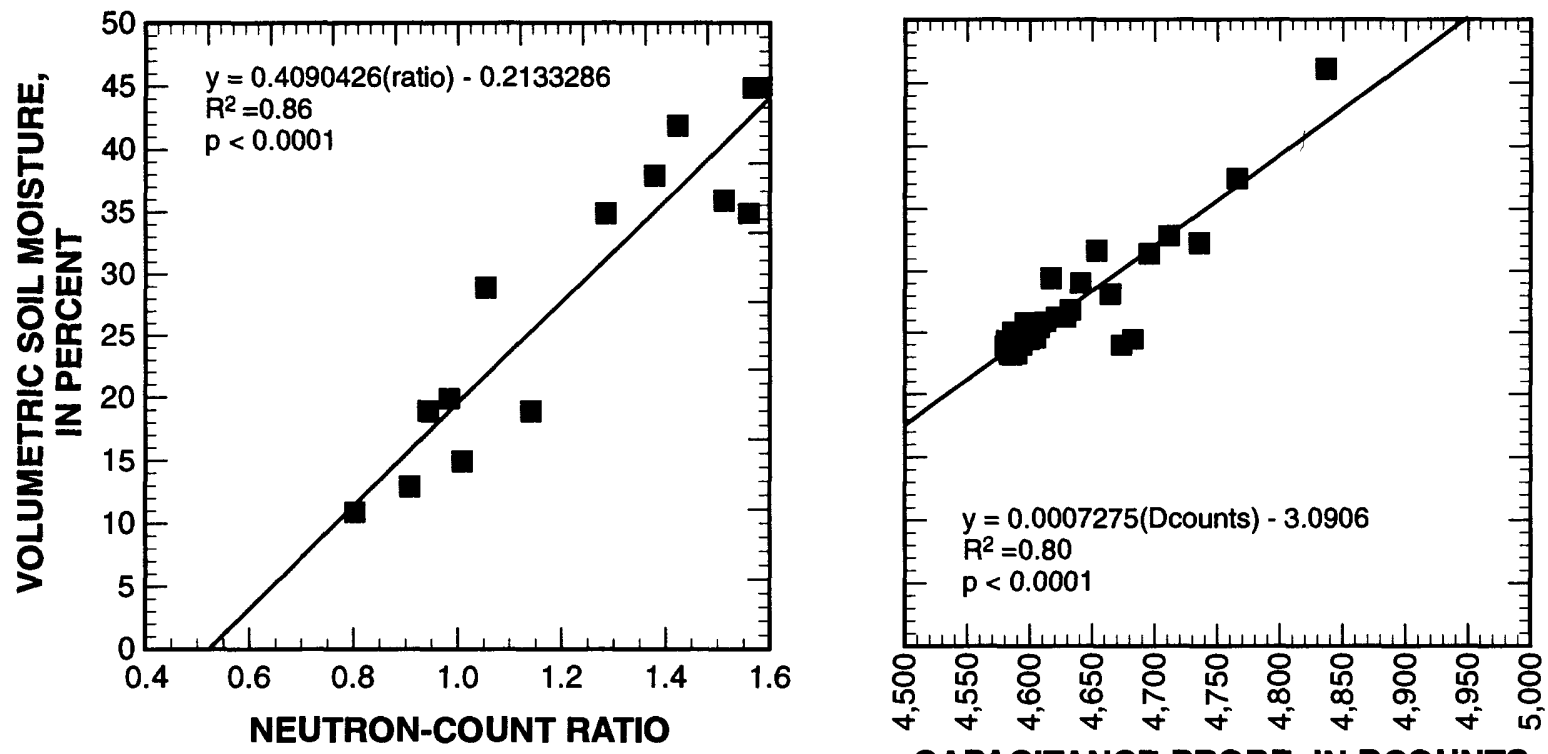

CAPACITANCE PROBE, IN DCOUNTS

Figure 5. Relation of volumetric soil-moisture content with neutron-count ratio and capacitance probe Dcounts, floodirrigated field, Milford area, Utah.

moisture measurements made at intervals in 1992 and daily in May and June of 1993 with the neutron probe, and continuously in 1993 with the capacitance probe. The quantity of irrigation water was measured periodically at the pump discharge pipe, under the sprinklers, and at the siphons into the field.

The water-budget equation used to estimate daily recharge to the basin-fill aquifer is

$$
R=P+I-E T-R O+\Delta S
$$

where:

$R$ is recharge,

$P$ is precipitation,

$I$ is irrigation water,

$E T$ is evapotranspiration,

$R O$ is runoff, and

$\Delta S$ is change in quantity of soil moisture in storage.

The individual components of this equation are discussed in the following sections.

\section{Precipitation}

Total precipitation during April 1 to September 15,1992 , was $6.70 \mathrm{~cm}$ (2.64 in.), and during April 1 to September 30, 1993, was $6.40 \mathrm{~cm}$ (2.52 in.). Daily precipitation is shown in figures 2 and 3 . Precipitation typically falls as rain during storms of short duration. The rain gage was unshielded; thus, gaged precipitation may be less than actual precipitation. Rain in April, May, and June was often associated with frontal passages, and most rain in July and August was associated with thunderstorms. Compared with other components of the water budget for irrigated fields in the Milford area, precipitation during the irrigation season is a relatively minor component.

\section{Irrigation Water}

The quantity of irrigation water applied to the flood-irrigated field was measured at the discharge pipe from the well and at the individual siphon tubes in the field. The farmers recorded or estimated dates when irrigation water was applied to the field. Water was applied to part of the field at about 0.98 to $1.14 \mathrm{~m}^{3} / \mathrm{min}$ 
( 0.18 to $0.20 \mathrm{ft}^{3} / \mathrm{min}$ ) through 12 to 16 siphon tubes covering about $7.1 \mathrm{~m}(23.3 \mathrm{ft})$ of the width of the field. Each irrigation application lasted about 12 hours. The farmers generally moved their siphon tubes in the morning and evening and water was applied to a set of furrows from about 7:00 a.m. to 7:00 p.m.; however, the movement of the siphon tubes also was subject to other activities and may have occurred as early as 6:00 a.m. and as late as 9:00 p.m. In this 12-hour period, about $26 \mathrm{~cm}$ (10.2 in.) of water was applied to the field, and application of water to the field is assumed to be uniform in distribution. The flood-irrigated field received a total of about $182 \mathrm{~cm}$ (71.6 in.) of water in 1992 and $156 \mathrm{~cm}$ (61.4 in.) in 1993. The upper end of a flood-irrigated field actually receives considerably more water than the lower end; however, a uniform application of water to the field was used to calculate the water budget because of the lack of data on the distribution of water throughout the field. The effects of this assumed distribution of irrigation water on the quantity of recharge are examined with the unsaturated-flow model and are discussed in the modeling section of this report.

The sprinkler-irrigated field was irrigated using a center-pivot sprinkler system that revolved every 3 to 4 days. The farmers recorded or estimated the dates the sprinkler system passed over the neutron-probe access tubes in the sprinkler-irrigated field. This record was. less complete and accurate than that of the flood-irrigated field. Output of the sprinkler system was measured periodically with calibrated buckets and a rain gauge in the field. The sprinkler applied 2.6 to $3.8 \mathrm{~cm}$ (1.0 in. to 1.5 in.) of water per revolution, which typically took 3 to 4 days. The sprinkler-irrigated field received about $52.8 \mathrm{~cm}$ (20.8 in.) of water in 1992 and $87.2 \mathrm{~cm}$ (34.3 in.) in 1993. Individual applications of irrigation water to the flood- and the sprinkler-irrigated field during the 1992 and 1993 irrigation seasons are shown in figure 6.

\section{Evapotranspiration}

Evapotranspiration was calculated using the Penman-Monteith combination equation (Allen and others, 1989; David Stannard, U.S. Geological Survey, written commun., 1992) in the form:

$$
\lambda E T=\frac{s\left((R N-G)+\frac{\rho c p(e s-e a)}{r h}\right)}{s+\gamma\left(\frac{r c+r h}{r h}\right)}
$$

where:

$\lambda E T$ is latent heat flux, $s$ is slope of saturation vapor-pressure curve, $R N$ is net radiation,

$G$ is soil heat flux,

$\rho$ is density of air,

$c p$ is specific heat of air,

es is saturation vapor pressure (Weiss, 1983;

Lowe, 1977),

$e a$ is saturation vapor pressure at dew point, $\gamma$ is psychrometric constant,

$r c$ is canopy resistance (Allen and others,

1989), and

$r h$ is aerodynamic resistance to vapor and heat diffusion (Campbell, 1977).

The Penman-Monteith equation (Monteith, 1963) used to estimate actual evapotranspiration is a modification of the Penman equation (Penman, 1956) for calculating potential evapotranspiration. Both are combination methods that combine energy balance and aerodynamic terms, and the Monteith variation includes the canopy resistance of the vegetation. The estimation of evapotranspiration for an arid grassland site with the Penman-Monteith equation is succinctly described by Tomlinson (1994) and includes an appendix with a step by step calculation of evapotranspiration using the Penman-Monteith equation. In this study, es and $e a$ were calculated using the equations from Lowe (1977) and Weiss (1983). Aerodynamic resistance to heat transfer, $r h$, is approximated by using the equation from Campbell (1977). Canopy resistance, $r c$, is typically not measured directly but is determined by computing the latent heat flux by other methods and then solving the Penman-Monteith equation for $r c$. The $r c$ value is highly variable and is a function of available moisture, stage of plant growth, canopy density, time of day, and climatic conditions. Studies in Arizona with well-watered alfalfa indicated that $r c$ is less than 100 seconds per meter ( 330 seconds per foot) for about 20 days after irrigation and then increases rapidly to about 2,500 seconds per meter $(8,200$ seconds per foot) during the next 11 days (Van Bavel, 1967). The $r c$ value also varies diurnally, approaching 0 at night and increasing toward 100 seconds per meter (330 seconds per foot) by midday (Van Bavel, 1967).

Because no actual measurements of evapotranspiration were made as part of this study, $r c$ was estimated using the method described by Allen and others (1989). This method calculates $r c$ as a function of leafarea index and average minimum daily value of sto- 

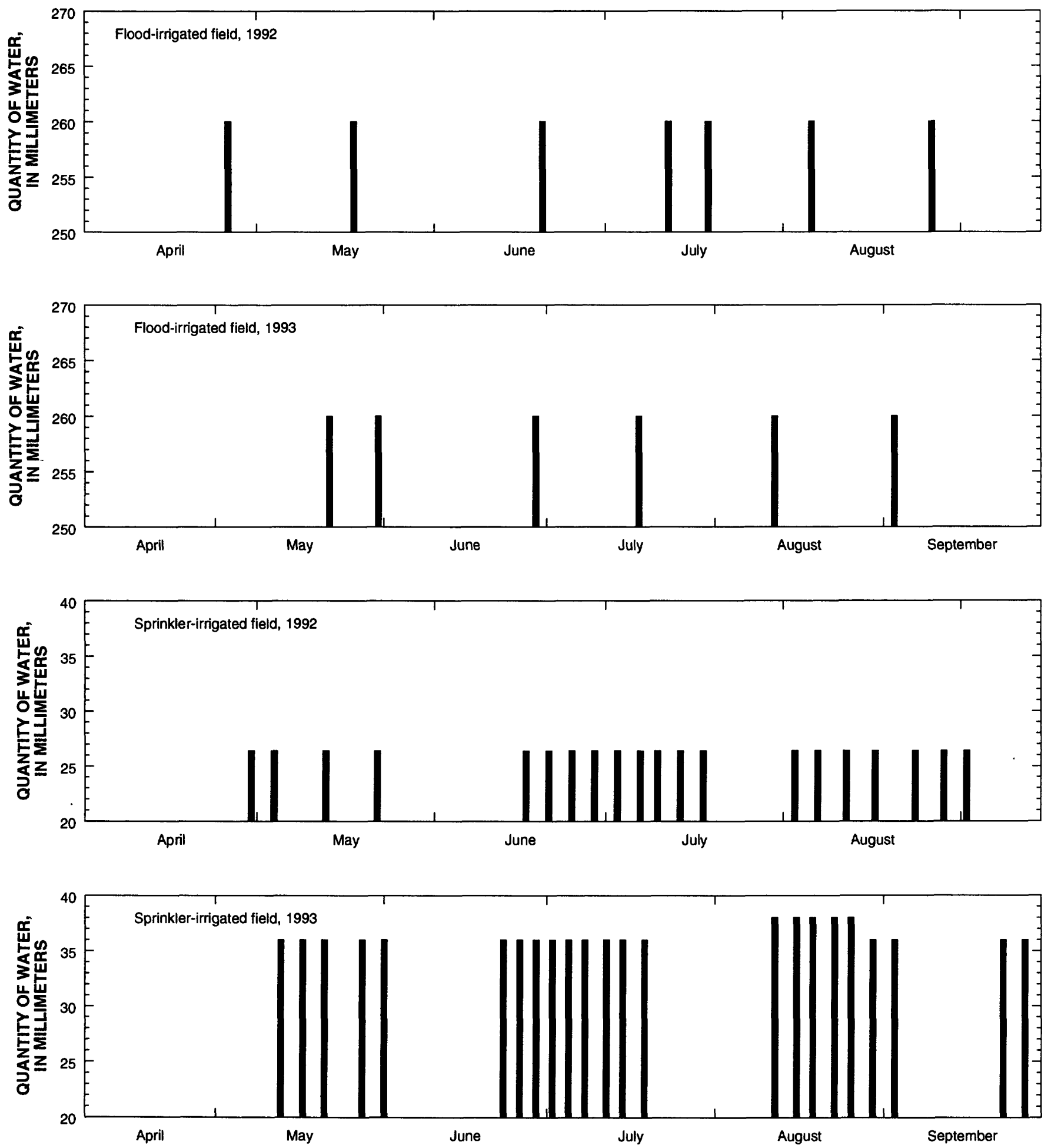

Figure 6. Application of irrigation water to the flood- and the sprinkler-irrigated field, Milford area, Utah, 1992 and 1993. 
matal resistance. Because leaf-area index is a function of crop height, the method accounts for the stage of plant growth. Evapotranspiration also was calculated using a constant $r c$ value, which resulted in larger estimates of evapotranspiration. These calculations did not account for the stage of plant growth and probably are less accurate than the estimates using a variable $r c$ value.

Evapotranspiration was calculated hourly from April 1 to September 15, 1992, and from April 1 to September 30,1993 . The hourly values were summed to provide daily estimates. Daily evapotranspiration ranged from 1.2 to $13.4 \mathrm{~mm} /$ day $(0.0039$ to $0.044 \mathrm{ft} /$ day) in 1992 and from 2.5 to $14.4 \mathrm{~mm} /$ day $(0.0082$ to $0.047 \mathrm{ft} /$ day) in 1993 (figs. 2 and 3). Cumulative evapotranspiration from April 1 to September 15, 1992, was $95.4 \mathrm{~cm}$ (37.6 in.) and for April 1 to September 30, 1993, was $84.3 \mathrm{~cm}$ (33.2 in.). These values are similar to the estimated annual crop consumptive use for alfalfa of $90.17 \mathrm{~cm}$ (35.50 in.) for the Milford area (R.W. Hill, Utah State University, written commun., 1994). Evapotranspiration was estimated for the flood-and the sprinkler-irrigated field from a single set of climate data that was collected between the two fields. This climate data represents an average data set for the area because the site was between the study fields, thus, evapotranspiration calculated from it may differ from evapotranspiration actually measured in the fields.

Daily evapotranspiration values missing in 1992 because of vandalism to the weather station were estimated from climate data obtained from the Utah Climate Center Milford weather station located about $3 \mathrm{~km}$ (1.9 mi) north of the study site (Utah Climate Center, written commun., 1993). The linear regression equation and relation between daily evapotranspiration calculated at the study site and at the Climate Center weather station are shown in figure 7 . The regression equation has an R-squared value of 66.88 , which is partly because the reference evapotranspiration calculated from the Climate Center weather-station data does not account for the variation in crop height, which is included in the evapotranspiration estimates at the study site, and because the Climate Center weather station was located in a nonvegetated field for the period of record. This data set is not ideal but was the only one available.

\section{Runoff}

Runoff is irrigation water that is applied to a field but does not infiltrate and is not consumed by plants and leaves the field through drainage ditches. Because irrigation water rarely reaches the lower end of the floodirrigated field, there is zero to only a small quantity of runoff. The alfalfa crop at the lower end of the floodirrigated field was wilted by early July, and soil moisture in the lower end of the field decreased during summer. For this water budget, there was assumed to be no runoff from the flood-irrigated field. Because the sprinkler-irrigated field is graded nearly level and the application rate of the water is slow, there is no runoff from the sprinkler-irrigated field either.

\section{Soil-Moisture Storage}

Soil-moisture measurements are used to determine changes in the quantity of soil moisture in storage. Soil moisture was measured with a neutron probe in the flood- and the sprinkler-irrigated field at about 2-week intervals in 1992 and was measured daily in May and part of June of 1993. Soil-moisture profiles for the flood- and the sprinkler-irrigated field for 1992 and May of 1993 (fig. 8) show the variability of soil moisture measured at about 2-week intervals and measured daily. The dates that soil moisture was measured are not shown on the graphs because individual lines on the graphs are very difficult to distinguish and because the variability defined by all the profiles is of interest. Soil moisture in the flood-irrigated field varies over a larger range than soil moisture in the sprinkler-irrigated field (fig. 8). The wettest soil-moisture profiles in the floodirrigated field were measured immediately after an irrigation application. Because the neutron-probe access tube partially filled with water during irrigation applications, it was not possible to measure a complete profile. The changes in soil moisture were very transient, and soil moisture generally fluctuated in a plus or minus 5-percent range. Soil moisture increased to saturation quickly during an irrigation application. The wetting fronts from each application moved through the soil column in about 48 hours, after which the soil returned approximately to its pre-irrigation moisture content.

Daily water content in the 600-cm (236-in.) soil profile in the flood-irrigated field and in the $570-\mathrm{cm}$ (224-in.) soil profile in the flood- and the sprinkler-irrigated field and change in daily water content are shown in figure 9. The flood-irrigated field was irrigated on 


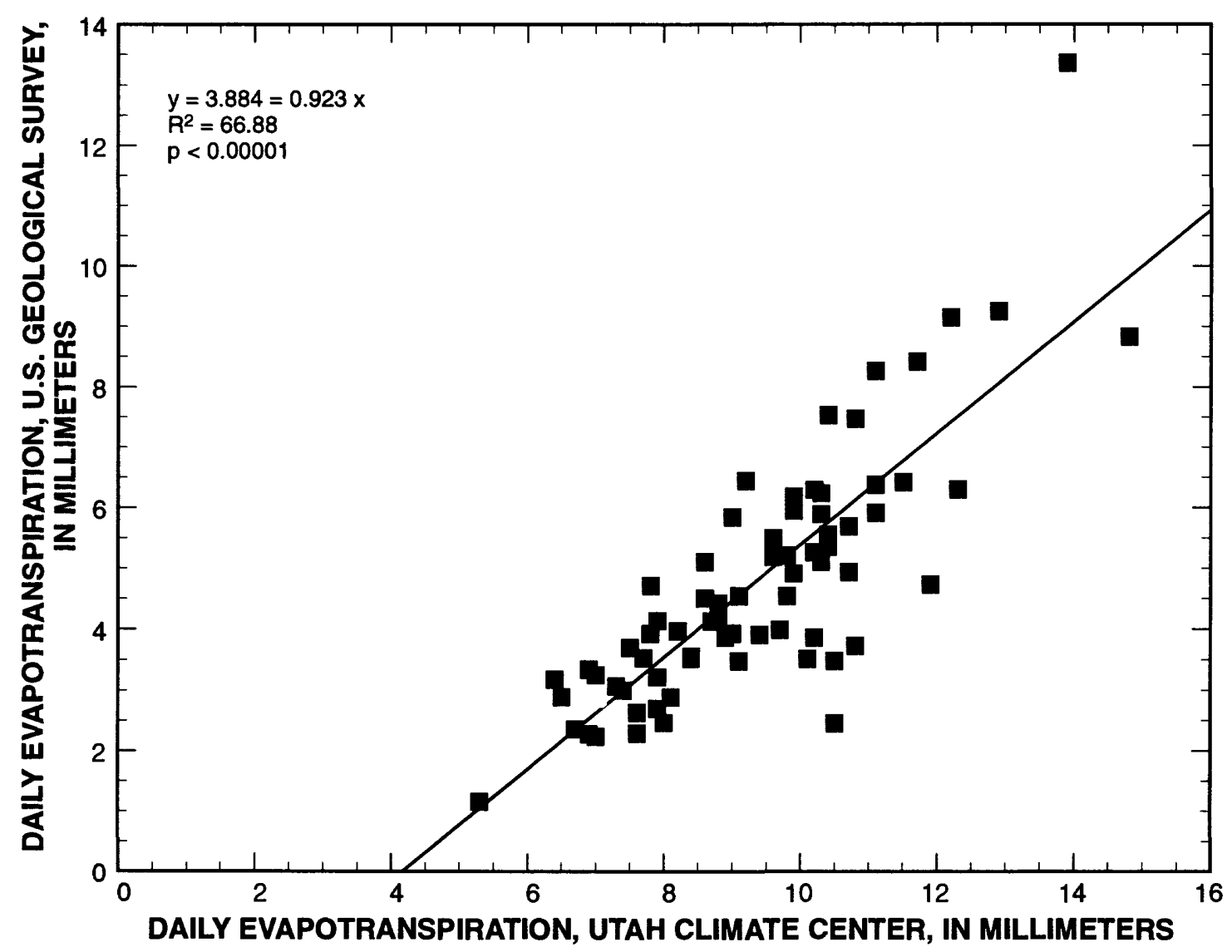

Figure 7. Relation between evapotranspiration data of the U.S. Geological Survey and Utah Climate Center, Milford area, Utah.

May 23, 1993, and it was not possible to measure soil moisture because of water in the access tube. The daily change in soil-moisture content in the flood- and the sprinkler-irrigated field was generally plus or minus 5 percent. The largest changes in moisture content are associated with irrigation applications and with shutting off the sprinkler system on about June 9,1993 , for the first cutting of the alfalfa.

Soil moisture also was measured continuously with capacitance probes at depths of $1.52 \mathrm{~m}(5.0 \mathrm{ft})$, $2.10 \mathrm{~m}(6.9 \mathrm{ft})$, and $3.65 \mathrm{~m}(12.0 \mathrm{ft})$. The data set for the flood-irrigated field during the 1993 irrigation season for the probe located at a depth of $1.52 \mathrm{~m}(5.0 \mathrm{ft})$ shows six irrigation events (fig. 10) during which $26 \mathrm{~cm}$ (10.2 in.) of water was applied to the field. The sudden 1-percent drop in soil-moisture content in the first week of August may be the result of recorder problems. In May, the soil-moisture content decreased to about 23 percent before the first irrigation application, and in September, the soil-moisture content decreased to about 25 percent. For the entire growing season, at a depth of $1.52 \mathrm{~m}(5.0$ $\mathrm{ft}$ ), there is only about a 4-percent change in soil-mois- ture content. This small change, along with the plus or minus 5-percent change in soil moisture observed in the soil-moisture profiles, indicates that soil-moisture changes are transient and that soil moisture remains within a small range during the entire growing season. Thus, for the water-budget calculations, the changes in soil-moisture storage during the irrigation season are assumed to be zero. The lower end of the flood-irrigated field was an exception. The quantity of irrigation water was insufficient to meet plant water requirements at the lower end of the field, and the entire soil profile dried out; however, for the water-budget calculations, it is also assumed that irrigation water is applied uniformly over the field.

\section{Recharge}

Recharge is water that infiltrates through the unsaturated zone and replenishes the basin-fill aquifer. In this study, water that reaches a depth of $6.4 \mathrm{~m} \mathrm{(21 \textrm {ft } )}$ is referred to as recharge. It is also referred to as deep percolation in other studies. Implicit in this definition 

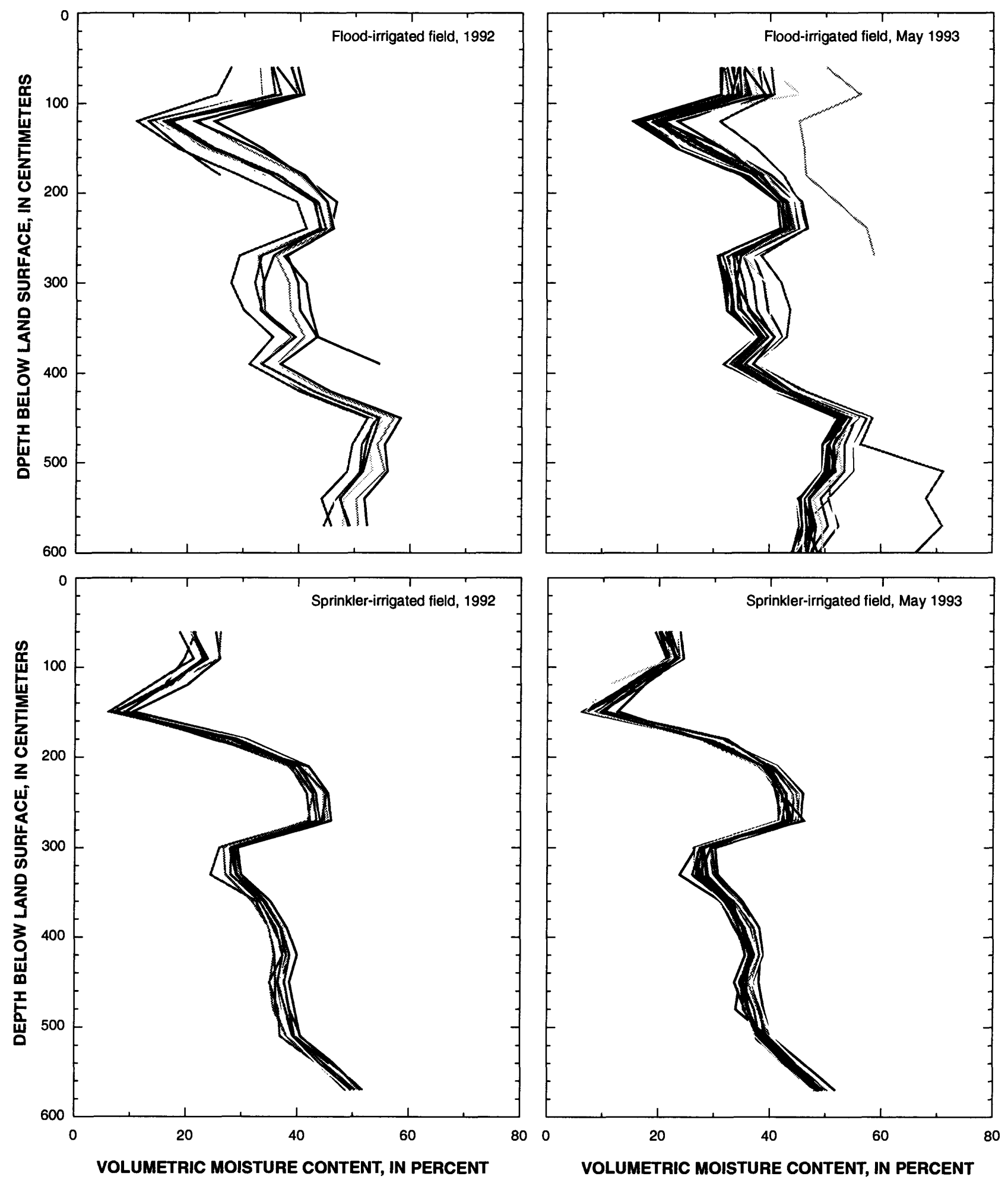

Figure 8. Volumetric soil-moisture profiles for the flood- and the sprinkler-irrigated field for the 1992 irrigation season and daily soil-moisture profiles for May 1993, Milford area, Utah. 

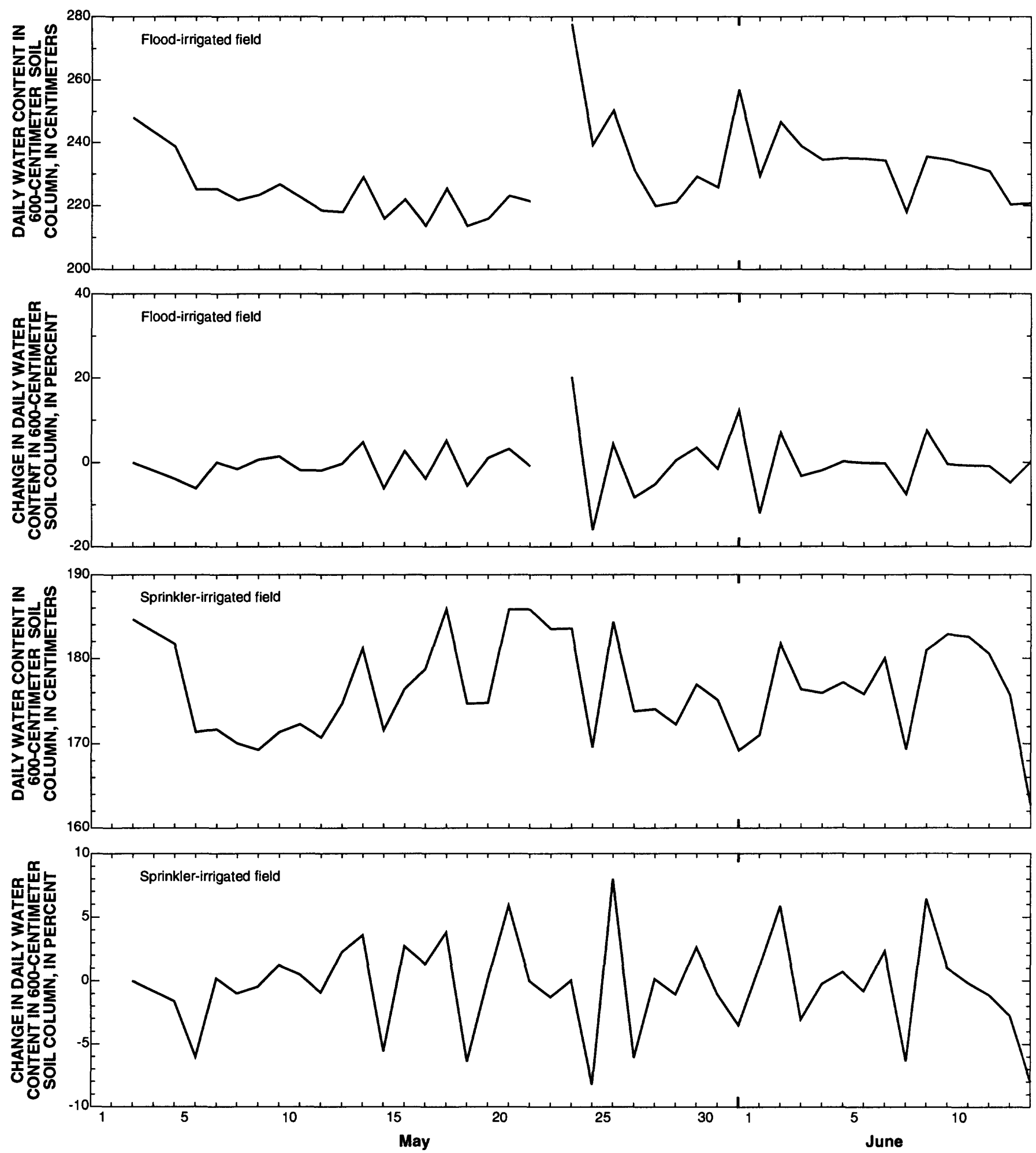

Figure 9. Daily water content and change in daily water content in a soil column in the flood- and the sprinkler-irrigated field, Milford area, Utah, May and June, 1993. 


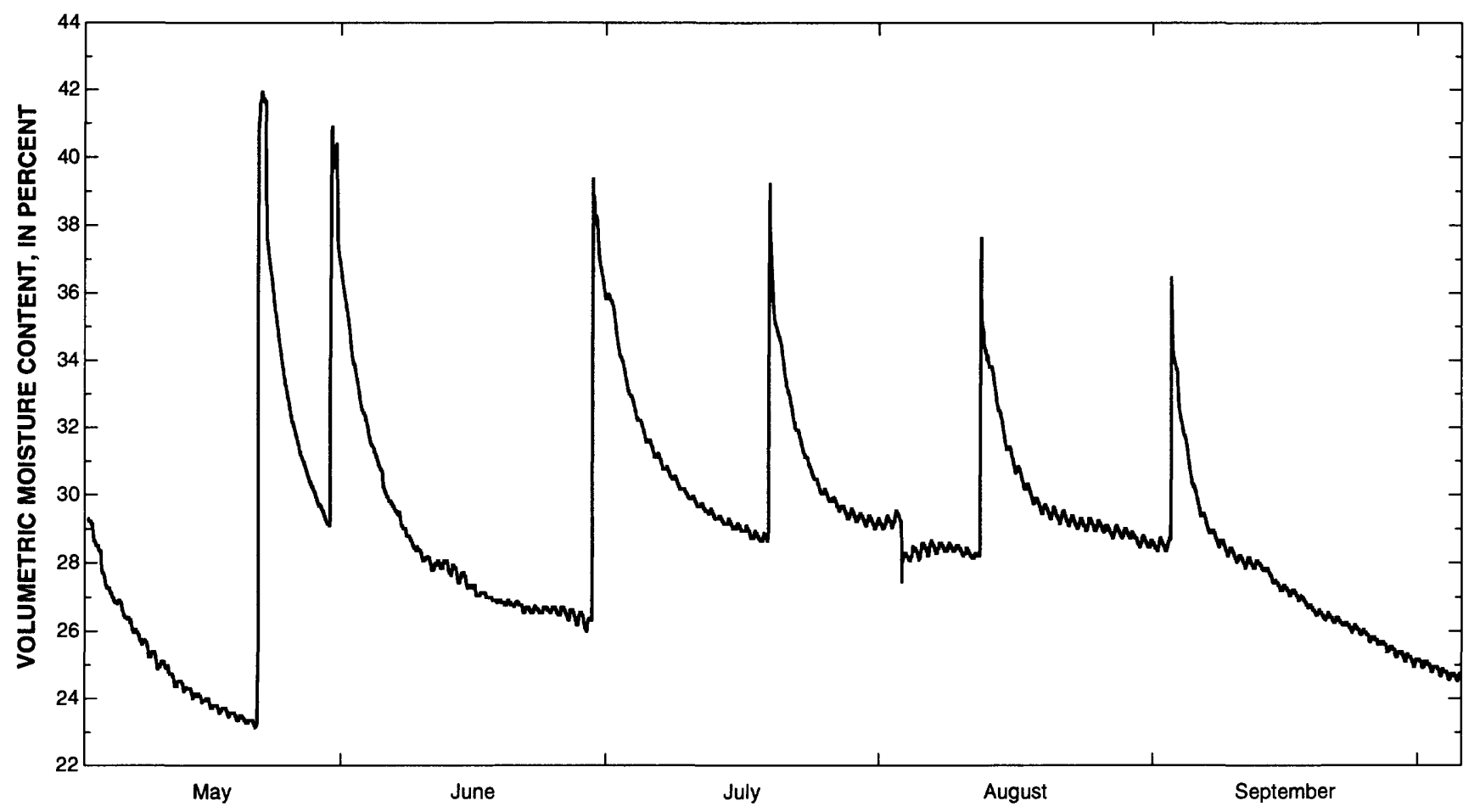

Figure 10. Volumetric soil-moisture content at a depth of 1.52 meters in the flood-irrigated field, Milford area, Utah, 1993. Six periods of irrigation during which 26 centimeters of water were applied are visible.

is the assumption that water that infiltrates to a depth of $6.4 \mathrm{~m}(21 \mathrm{ft})$ recharges the basin-fill aquifer. At $6.4 \mathrm{~m}$ (21 ft), the water is below the root zone of most plants and thus has the potential to recharge the basin-fill aquifer. However, it cannot be known for certain that water that infiltrates to $6.4 \mathrm{~m}(21 \mathrm{ft})$ actually reaches the water table. There is evidence that vapor transport removes water from great depths in the unsaturated zone. The unsaturated basin-fill deposits below $6.4 \mathrm{~m}(21 \mathrm{ft})$ were not monitored because of the cost of drilling monitoring wells to the water table. In the water budget for the flood- and the sprinkler-irrigated field (fig. 11), the precipitation and irrigation components of the water budget are summed and runoff and change in soil-moisture content are assumed to be zero as discussed previously. Cumulative recharge is determined by subtracting cumulative evapotranspiration from the cumulative sum of precipitation and irrigation. If cumulative recharge is positive, then water is available to recharge the aquifer. If cumulative recharge is negative, then the crop is receiving insufficient water to meet plant water requirements. The water budget for the two fields is summarized at the top of page 19.
Estimated recharge for the flood-irrigated field in 1992 was $93.3 \mathrm{~cm}$ (36.7 in.) and in 1993 was $78.1 \mathrm{~cm}$ (30.7 in.). Estimated recharge is 49 and 48 percent, respectively, of the sum of precipitation and irrigation during April to September in 1992 and 1993, assuming that change in the quantity of soil moisture in storage and runoff from the field is zero and that 100 percent of precipitation is effective. If there is an increase in moisture stored in the soil or if there is runoff from the field, then recharge would decrease. The recharge could be attributed to the large volume of irrigation water that is applied in about 12 hours and to the hydraulic characteristics of the soil.

Estimated recharge in the sprinkler-irrigated field in 1992 of $-35.9 \mathrm{~cm}(-14.1 \mathrm{in}$.) indicates that insufficient moisture was available to satisfy plant water requirements and that no recharge occurred in 1992. In 1993, there was $9.3 \mathrm{~cm}$ ( $3.7 \mathrm{in}$.) of recharge. Precipitation plus irrigation for 1993 was $34.1 \mathrm{~cm}$ (13.4 in.) greater than in 1992, and evapotranspiration was less in 1993. These factors account for the estimated recharge in 1993. The farmers applied more water and adjusted their sprinklers more often in 1993 than in 1992 so that the application rate changed frequently during the irrigation 

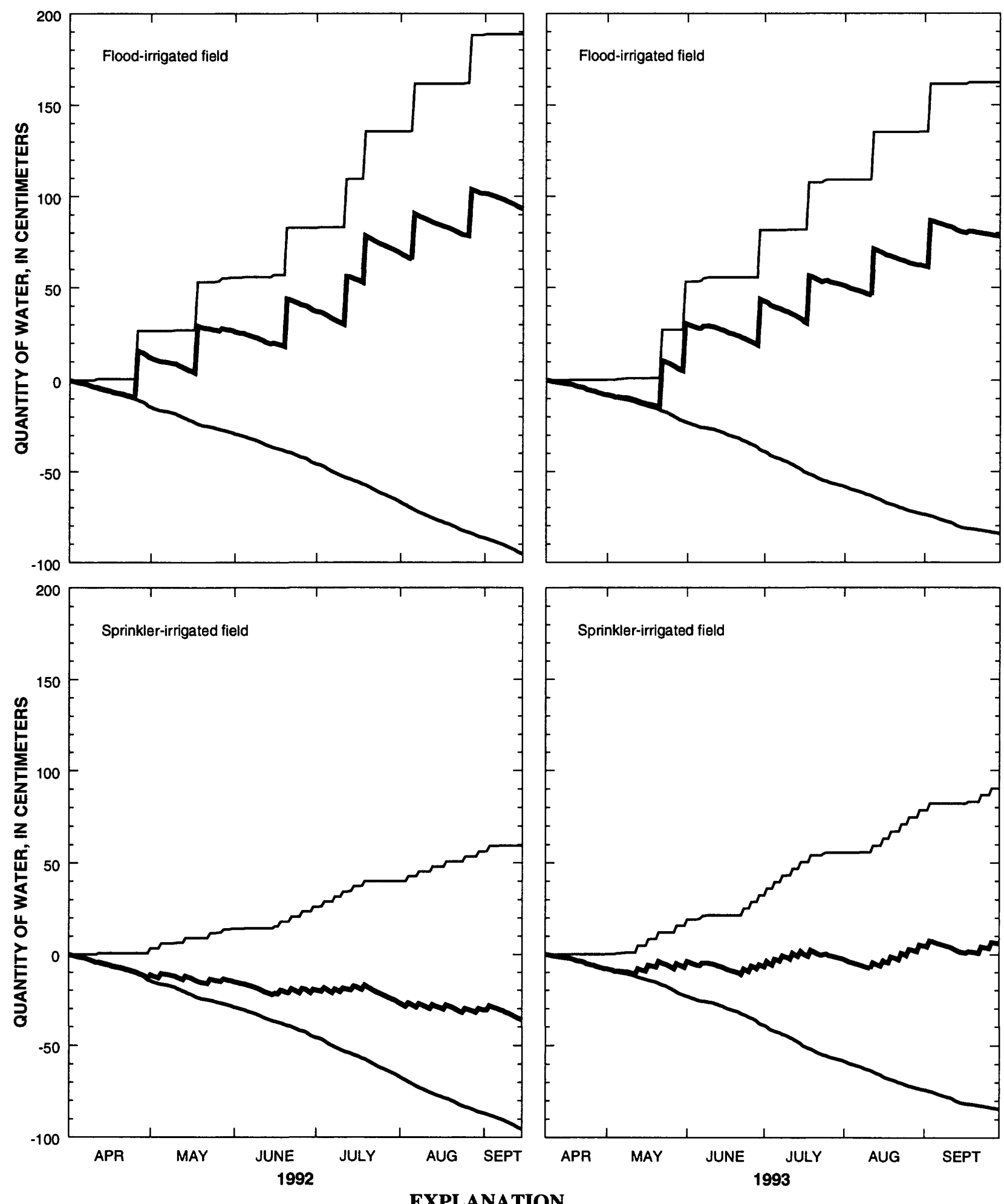

EXPLANATION

Cumulative precipitation and irrigation

Cumulative precipitation and irrigation minus cumulative evapotranspiration (Cumulative recharge) Cumulative evapotranspiration

Figure 11. Water budget for the flood- and the sprinkler-irrigated field for 1992 and 1993 irrigation seasons, Milford area, Utah. 


\begin{tabular}{|c|c|c|c|c|c|c|}
\hline $\begin{array}{l}\text { Field and } \\
\text { year }\end{array}$ & $\begin{array}{l}\text { Evapotranspiration } \\
\text { (centimeters) }\end{array}$ & $\begin{array}{l}\text { Irrigation plus } \\
\text { precipitation } \\
\text { (centimeters) }\end{array}$ & $\begin{array}{c}\text { Recharge } \\
\text { (centimeters) }\end{array}$ & $\begin{array}{l}\text { Change in soil- } \\
\text { moisture storage } \\
\text { (centimeters) }\end{array}$ & $\begin{array}{c}\text { Runoff } \\
\text { (centimeters) }\end{array}$ & $\begin{array}{l}\text { Irrigation plus } \\
\text { precipitation water } \\
\text { that is recharge } \\
\text { (percent) }\end{array}$ \\
\hline Flood, 1992 & 95.4 & 188.7 & 93.3 & 0 & 0 & 49 \\
\hline Flood, 1993 & 84.3 & 162.4 & 78.1 & 0 & 0 & 48 \\
\hline Sprinkler, 1992 & 95.4 & 59.5 & -35.9 & 0 & 0 & 0 \\
\hline
\end{tabular}

season (Troy Hardy, farmer, oral commun., 1993). For the water budget, application rates of 3.6 or $3.8 \mathrm{~cm}$ (1.4 or $1.5 \mathrm{in}$.) per rotation were used. These rates were the maximum rates measured in the fields. If the 1992 application rate of $2.6 \mathrm{~cm}$ ( $1.0 \mathrm{in}$.) per rotation were used for 1993, there would be no recharge in 1993.

Water moving through the unsaturated zone is assumed to move only in the vertical direction. This assumption is required because data were not collected on flow in the unsaturated zone in the horizontal direction. Other detailed studies of flow in the unsaturated zone have noted a component of flow in the horizontal direction and large heterogeneities in soil hydraulic properties in the horizontal direction (Bowman and others, 1991). If horizontal flow occurs in the root zone, which includes about the upper $1.52 \mathrm{~m}(5.0 \mathrm{ft})$ of soil, then water could be distributed in the unsaturated zone and removed by evapotranspiration in the fields or beyond the boundaries of the fields. The net result would be to decrease the amount of recharge. Soilmoisture measurements in the lower end of the floodirrigated field do not indicate that horizontal flow is occurring in the upper $3.5 \mathrm{~m}$ (11.5 ft) of soil; however, horizontal flow could be occurring below this depth.

The drillers' logs from 18 wells located within 2 $\mathrm{km}(1.2 \mathrm{mi})$ of the study site were examined to see if there were any continuous, thick clay layers in the basin fill that would prevent infiltrating water from reaching the basin-fill aquifer. Because the water levels in the basin-fill aquifer are generally 15 to $30 \mathrm{~m}$ (49 to $98 \mathrm{ft}$ ) below land surface near the study site, the upper $30 \mathrm{~m}$ (98 ft) were examined in each drillers' log. Clay layers greater than $6 \mathrm{~m}(20 \mathrm{ft})$ thick were noted because a clay layer of this thickness would provide hydraulic resistance to vertical flow and would probably be recorded on a driller's log. Only five of the driller's logs recorded clay layers greater than $6 \mathrm{~m}(20 \mathrm{ft})$ thick in the upper 30 $\mathrm{m}(98 \mathrm{ft})$ of the well. On the basis of the drillers' logs, these clay layers could not be correlated among wells. There is no continuous clay layer in the basin fill near the study area that would impede or prevent irrigation water from infiltrating and recharging the basin-fill aquifer.

\section{SIMULATION OF ONE-DIMENSIONAL UNSATURATED FLOW}

The U.S. Geological Survey unsaturated-flow model VS2DT (Lappala, and others, 1983; Healy, 1990) was used to simulate vertical infiltration through the upper $6.4 \mathrm{~m}(21 \mathrm{ft})$ of the unsaturated zone. Water that infiltrated to a depth of $6.4 \mathrm{~m}(21 \mathrm{ft})$ was assumed to recharge the basin-fill aquifer because it would eventually drain through the entire unsaturated zone to the water table. A one-dimensional simulation was used because of lack of sufficient data for a two-dimensional simulation and because of the heterogeneity of the basin-fill deposits.

The model was constructed and calibrated using measured and estimated water-budget components and soil-moisture profiles from the flood-and the sprinklerirrigated field. The data were collected during the 1992 and 1993 irrigation seasons (April to September). The model was used to simulate ground-water recharge from different irrigation methods and was used to investigate the effects of irrigation method and waterapplication rates and distributions on ground-water recharge.

Because the soil characteristics for the flood-and the sprinkler-irrigated field are similar, they were averaged to create the soil column used in the model. The average soil column allows for direct comparison of the simulated water-budget components of the two fields. The model simulates unsaturated flow at the upper end of the flood-irrigated field and in the sprinkler-irrigated 
field. The model simulates daily evapotranspiration, infiltration into the soil column, flow out of the soil column, and the change in quantity of soil moisture in storage in the soil column.

\section{Discretization}

The model is defined to simulate one-dimensional vertical flow. A 6.4-m (21-ft) column was subdivided into $6410-\mathrm{cm}$ (3.9-in.) cells. This discretization allowed for adequate representation of the layering in the unsaturated zone. The model consists of four textural classes and five-layers (fig. 12). A textural class is defined by a set of soil properties. The textural classes were determined from log probability plots of particlesize distribution of clay, silt, and sand (Klusman, 1980, p. 28). The subpopulations determined in the log probability plots define three textural classes, with each textural class having a specified range of clay, silt, and sand. The three textural classes, however, failed to adequately reproduce the soil-moisture profiles observed in the field. A fourth textural class therefore was created.

The end points of the clay and sand subpopulation and the sand/clay ratio subpopulation for each textural class were overlaid on the particle-size distribution of the soil profile used in the model (fig. 12 ), and five to eight layers were defined. The layering is defined by particle-size distribution and also is a function of the core-sampling interval. Sample cores were collected at selected representative intervals. The soil data from these samples were used in adjacent unsampled intervals. Five layers were used in the model because this was the simplest model possible and the layers were well defined by the data (fig. 12).

\section{Boundary Conditions}

The model is defined with active nodes at the top and bottom of the soil column and no-flow boundaries on the sides of the column. The top boundary condition changed from an evapotranspiration boundary to a specified-flux boundary when irrigation water was being applied. The specified-flux boundary accounts for ponding on the surface and can switch to a specified-potential boundary when ponding occurs (Lappala and others, 1983, p. 38). This option was required in the flood-irrigated field. The lower boundary condition was a seepage face (Lappala and others, 1983, p. 44).

Because water is assumed to recharge the ground-water system after it infiltrates the upper $6.4 \mathrm{~m}(21 \mathrm{ft})$ of the unsaturated zone, a seepage water-table interface was used to simulate flux at the bottom of the soil column. Internal sinks, such as plant root extraction to a depth of $130 \mathrm{~cm}(51 \mathrm{in}$.$) , also were used in the simulation.$

\section{Parameters}

The initial soil-moisture content of the soil column was set to equilibrium with a negative hydraulic head of $-300 \mathrm{~cm}(-120 \mathrm{in}$.) of water. The soil-moisture profile resulting from this head was similar to the soilmoisture profiles measured in the field and simulated with the model. This initial condition also provided enough water in the soil column to satisfy plant water requirements before the first application of irrigation water.

The soil properties and derived parameters required by the model are saturated hydraulic conductivity, specific storage, porosity, and the van Genuchten equation parameters $\alpha, \theta_{\mathrm{r}}$, and $\beta$. The van Genuchten equation describes the relation between soil-moisture content and negative pressure head, often referred to as the moisture characteristic curve (Lappala and others, 1983). Lappala and others (1983) have reformulated the van Genuchten equation and use parameters $-\alpha^{\prime}, \theta_{\mathrm{r}}$, and $\beta^{\prime}$. Soil properties were determined from laboratory analyses, selected from tables of parameters based on textural class, and calculated from laboratory data. If multiple laboratory analyses were available for a soil interval, the laboratory-determined parameters were averaged and the average value for the textural class was used. The initial values used in the model are listed by textural class at the top of page 22 .

Saturated hydraulic conductivity was determined by using a falling-head permeameter for selected cores collected when the neutron-probe access holes were drilled. Laboratory saturated hydraulic-conductivity values ranged from 0.21 to $21 \mathrm{~cm} /$ day $(0.0069$ to 0.69 $\mathrm{ft} /$ day). These data were compared with tabulated data of Lappala and others (1983) and Rawls and others (1982) and were generally less than reported values for a textural class. Saturated hydraulic conductivity for a given soil texture can vary by several orders of magnitude. Specific storage is generally very small and was set to $1 \times 10^{-6} / \mathrm{cm}\left(3.9 \times 10^{-7} / \mathrm{in}\right.$.) for each textural class (R.W. Healy, U.S. Geological Survey, oral commun., 1992). Porosity was determined by laboratory analyses of the clod and core samples. 


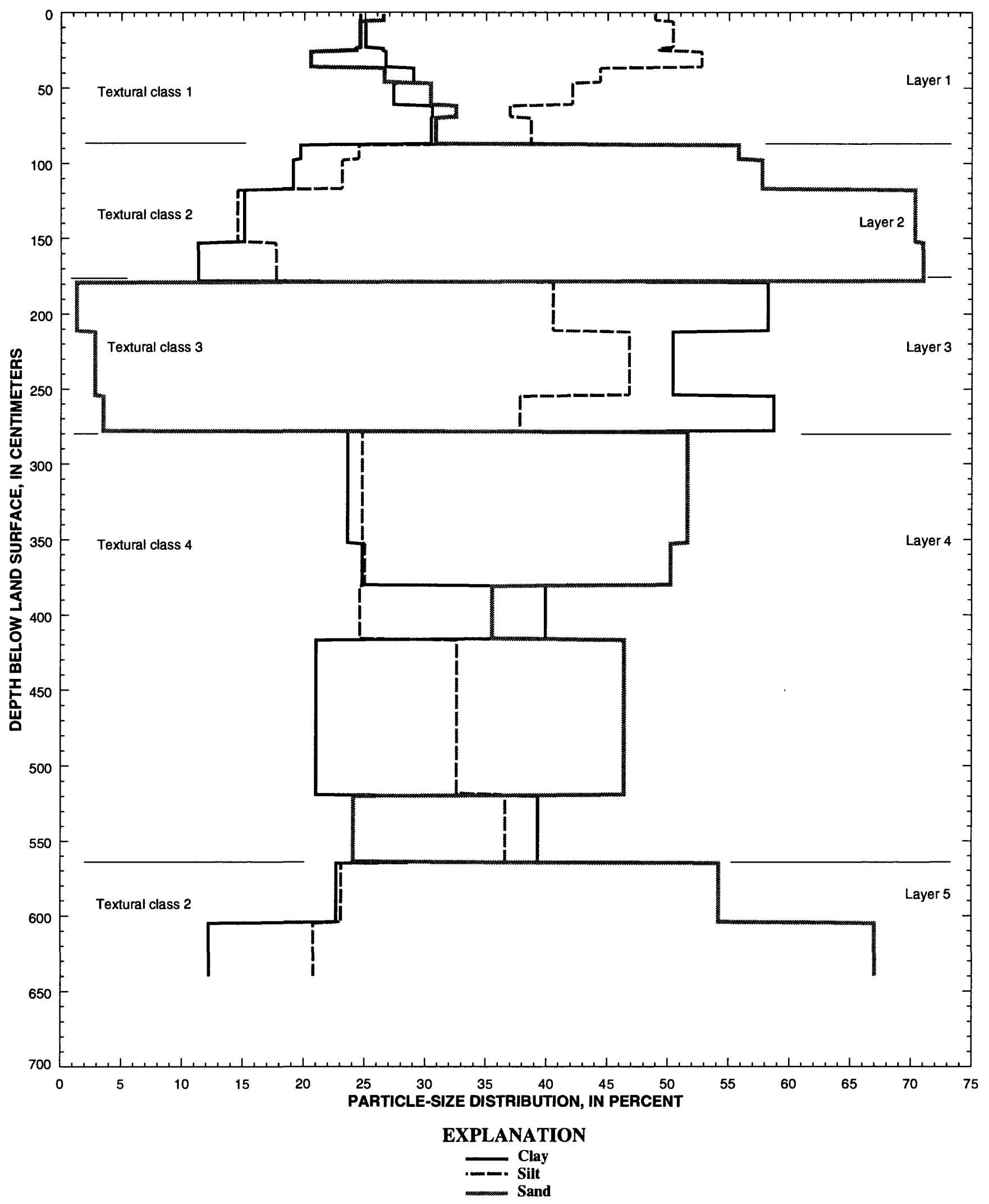

Figure 12. Composite average particle-size distribution in soil clods from two pits and soil cores from four neutron-probe access holes in the flood- and the sprinkler-irrigated field, and unsaturated-flow-model textural classes and layers, Milford area, Utah. 


\begin{tabular}{ccccccc}
\hline $\begin{array}{c}\text { Textural } \\
\text { class }\end{array}$ & $\begin{array}{c}\text { Saturated } \\
\text { hydraulic } \\
\text { conductivity } \\
\text { (centimeters } \\
\text { per day) }\end{array}$ & $\begin{array}{c}\text { Specific } \\
\text { storage } \\
\text { (per } \\
\text { centimeter) }\end{array}$ & Porosity & $\begin{array}{c}\text { van Genuchten } \\
-\alpha \\
\text { (centimeters) }\end{array}$ & $\begin{array}{c}\text { van Genuchten } \\
\text { residual } \\
\text { moisture } \\
\text { content, } \theta_{\mathbf{r}}\end{array}$ & $\begin{array}{c}\text { van Genuchten } \\
\beta^{\prime}\end{array}$ \\
\hline 1 & 6.9 & $1 \times 10^{-6}$ & 0.45 & -800 & 0.12 & 2.5 \\
2 & 86.0 & $1 \times 10^{-6}$ & .38 & -80 & .082 & .05 \\
3 & 2.0 & $1 \times 10^{-6}$ & .47 & $-3,300$ & .165 & 1.6 \\
4 & 10.0 & $1 \times 10^{-6}$ & .42 & -150 & .15 & 2.0 \\
\hline
\end{tabular}

The van Genuchten equation relating soil moisture and negative hydraulic head has the three coefficients $-\alpha^{\prime}, \theta_{\Gamma}$ and $\beta^{\prime}$ (Lappala and others, 1983) where $-\alpha^{\prime}$ is a scaling factor and $\beta^{\prime}$ is a pore-size distribution parameter. The parameters $-\alpha$ ' and $\beta^{\prime}$ 'were estimated for each textural class by fitting the laboratory-determined soil-moisture characteristic curves with the van Genuchten equation. The residual moisture content, $\theta_{\mathrm{r}}$ is determined in the laboratory.

Evapotranspiration was simulated using monthly cycles. The values used in the model are mean monthly values of the average daily evapotranspiration. The model accounts for plant-root extraction from the unsaturated zone and requires the input of the root-pressure potential, plant-root activity function, and root depth (Lappala and others, 1983). Root-pressure potential was set to $-10,000 \mathrm{~cm}(-3,940 \mathrm{in}$.) of water (Lappala and others, 1983). The plant-root activity function in the model is a linear function, and the top and bottom end points of the function are required and ranged from 0.35 to $0.90 \mathrm{~cm}^{-2}$ ( 0.14 to 0.35 in. $\left.^{-2}\right)$. Root depths were set from 100 to $130 \mathrm{~cm}$ (39.4 to $51.2 \mathrm{in}$.) on the basis of observations in the soil pits and on the laboratory-determined organic carbon content of soil clods and cores.

The model input is divided into recharge periods (Lappala and others, 1983). A recharge period is a time period when the recharge or evapotranspiration, boundary conditions, and iteration parameters are specified. The recharge periods for the simulations were defined by the application of irrigation water to each field. Each day the fields were irrigated was a recharge period, and the days between applications also were defined as recharge periods even though no recharge was occurring. For example, the center-pivot sprinkler rotated around the field once every 3 to 4 days; thus, the day the sprinkler system passed over the field instruments would be a 1-day recharge period when water was applied to the field. This recharge period would be fol- lowed by a 3-day recharge period when no water was applied but evapotranspiration occurred. Simulation in the flood-irrigated field consisted of 15 (1992) and 13 (1993) recharge periods, and simulation in the sprinkler-irrigated field consisted of 41 (1992) and 56 (1993) recharge periods.

\section{Calibration}

The model was calibrated to the water budget (fig. 11) and to the soil-moisture profiles for the upper 6 $\mathrm{m}(20 \mathrm{ft})$ of the unsaturated zone (fig. 8). No runoff from the field was assumed. This assumption is important because several of the laboratory-derived model input parameters were modified to ensure that there was no runoff from the field. Because the soil profile used in the model is a composite profile, reproduction of the actual soil-moisture profiles was not possible. However, the simulated soil-moisture profiles reflect the general shape of the actual soil-moisture profiles (figs. 8 and 13) and indicate that the simulated profiles are representative of actual soil texture. The simulated soilmoisture profiles were calibrated to reproduce the soilmoisture variations observed in the field.

Saturated hydraulic conductivity for a soil texture can vary by several orders of magnitude. Laboratory saturated hydraulic-conductivity values from cores collected in this study are less than tabulated values for similar textural classes (Lappala and others, 1983; Rawls and others, 1982). These lower values may be a result of compaction of the samples during collection by using a trailer-mounted auger and core barrel. Saturated hydraulic-conductivity values measured in the field also are often more than an order of magnitude larger than those measured in the laboratory (R.W. Healy, U.S. Geological Survey, oral commun., 1993). The saturated hydraulic-conductivity values used as initial conditions were laboratory values and were mod- 

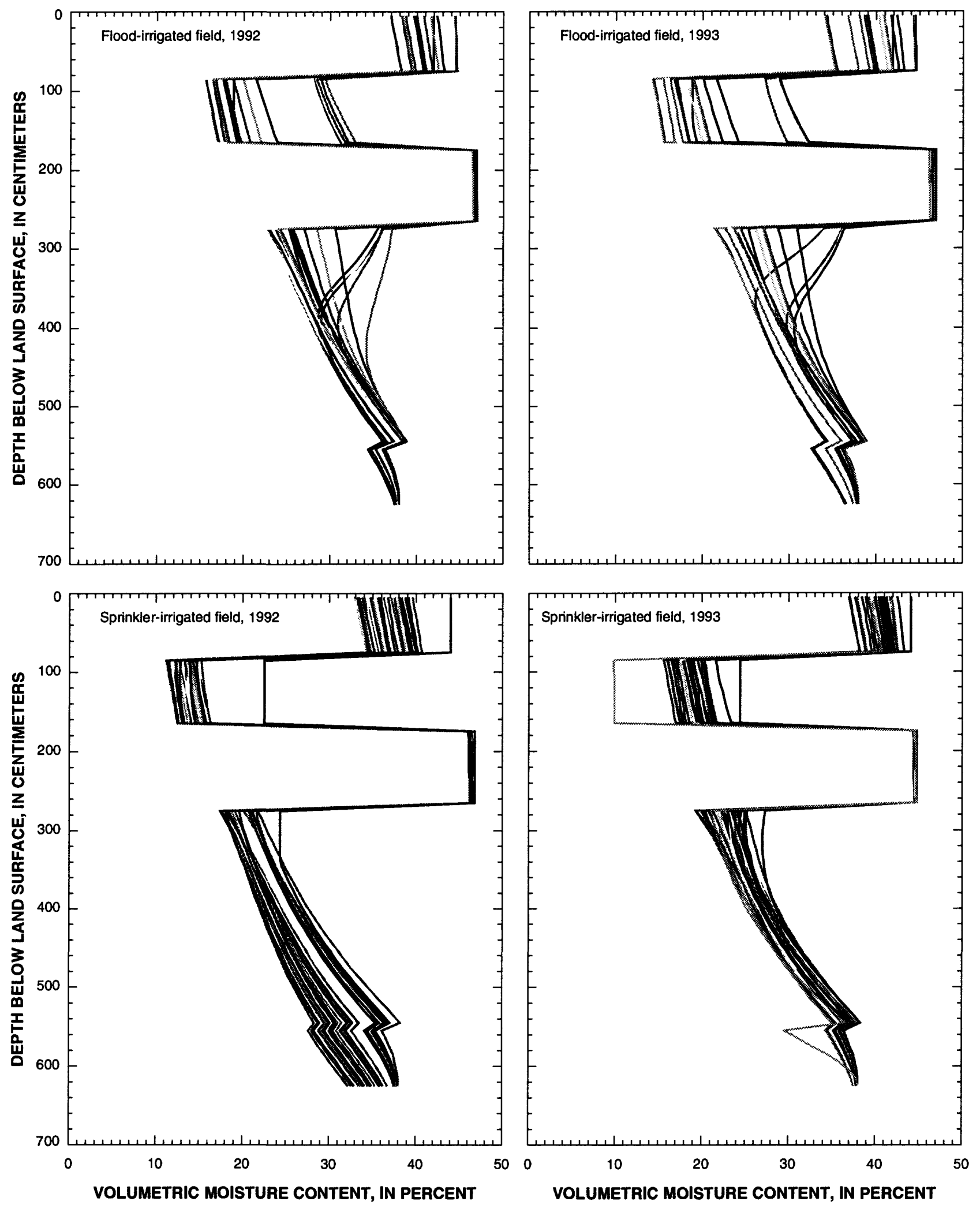

Figure 13. Simulated daily soil-moisture profiles in the flood- and the sprinkler-irrigated field for 1992 and 1993 irrigation seasons, Milford area, Utah. 
ified during calibration. The modifications maintained the relative differences among the model textural classes as much as possible. The other model parameters have smaller ranges, and adjustments to these parameters during calibration were minimized.

Saturated hydraulic conductivity in each textural class was varied in the following ranges:

\begin{tabular}{ccc}
\hline $\begin{array}{c}\text { Textural } \\
\text { class }\end{array}$ & $\begin{array}{c}\text { Initial conditions } \\
\text { (centimeters } \\
\text { per day) }\end{array}$ & $\begin{array}{c}\text { Range } \\
\text { (centimeters } \\
\text { per day) }\end{array}$ \\
\hline 1 & 6.9 & $6.9-700$ \\
2 & 86 & $86-8,600$ \\
3 & 4 & $4-400$ \\
4 & 10 & $10-1,000$ \\
\hline
\end{tabular}

Simulations using the initial laboratory values of saturated hydraulic conductivity were not possible because the model numerically failed to converge. The numerical problem was in the first layer with the application of $26 \mathrm{~cm}$ (10 in.) of water in the 1-day recharge period. The model numerically converged if saturated hydraulic conductivity was increased from 6.9 to 14 $\mathrm{cm} /$ day ( 0.23 to $0.46 \mathrm{ft} /$ day) in textural class 1 , but surface runoff was generated, recharge was less than in the field water budget, and there were large changes in soil moisture. To prevent runoff and large changes in soil moisture, it was necessary to increase saturated hydraulic-conductivity values in all the textural classes. The field water budget and the simulated water budget were similar for simulations in which initial saturated hydraulic conductivity was increased by a factor greater than 2; however, the soil-moisture profile had ponding on layer 3 and experienced soil-moisture variations greater than 20 percent. Saturated hydraulic-conductivity values in the calibrated model were increased by a factor of 10 over the initial laboratory values. Field saturated hydraulic-conductivity values typically are greater than laboratory values because the laboratory core samples do not sample larger soil structure that can affect conductivity values (Rick Healy, U.S. Geological Survey, oral commun., 1993). Saturated hydraulic conductivity was increased from 20 to $40 \mathrm{~cm} /$ day $(0.66$ to $1.3 \mathrm{ft} /$ day) to reduce ponding on layer 3 . The simulated water budget was similar to the field water budget (fig. 11) when these hydraulic-conductivity values were used, but variations in soil moisture were still greater than 20 percent in the soil-moisture profile.

The van Genuchten - $\alpha$ ' parameter partly controls variation in soil moisture in a textural class. In textural classes 1 and $2,-\alpha$ ' was decreased from -800 to $-1,000$ (textural class 1) and from -80 to -200 (textural class 2 ) to decrease the variability of the soil-moisture profiles. The objective was to limit the range of soil moisture in these textural classes to less than 20 percent with most of the variation in soil moisture in a layer less than 10 percent.

The soil hydraulic parameters for the calibrated model are listed at the bottom of this page.

The simulated cumulative water budget is shown in figure 14 and the estimated and simulated water budget is summarized in table 2 . The simulated water-budget components are generally within $5 \mathrm{~cm}$ ( 2 in.) of the estimated water budget. Recharge simulated for 1992 is the result of drainage from the initial soil profile (fig. 13 ), and there is no recharge in the sprinkler-irrigated field in 1992. The variations in simulated soil moisture (fig. 13) are less than 20 percent, with most of the variation in the soil-moisture profile in the 10-percent range. The variations in the simulated soil-moisture profiles are greater than in the field soil-moisture profiles. To reduce these variations would require large changes in the van Genuchten parameters, which are a function of soil texture. The difference in evapotranspi-

\begin{tabular}{ccccccc}
\hline $\begin{array}{c}\text { Textural } \\
\text { class }\end{array}$ & $\begin{array}{c}\text { Saturated } \\
\text { hydraulic } \\
\text { conductivity } \\
\text { (centimeters } \\
\text { per day) }\end{array}$ & $\begin{array}{c}\text { Specific } \\
\text { storage } \\
\text { (per } \\
\text { centimeter) }\end{array}$ & Porosity & $\begin{array}{c}\text { van Genuchten } \\
-\alpha^{\prime} \\
\text { (centimeters) }\end{array}$ & $\begin{array}{c}\text { van Genuchten } \\
\text { residual } \\
\text { moisture } \\
\text { content, } \theta_{\mathbf{r}}\end{array}$ & $\begin{array}{c}\text { van Genuchten } \\
\beta^{\prime}\end{array}$ \\
\hline 1 & 69 & $1 \times 10^{-6}$ & 0.45 & $-1,000$ & 0.12 & .082 \\
2 & 860 & $1 \times 10^{-6}$ & .38 & -200 & .165 & 2.05 \\
3 & 40 & $1 \times 10^{-6}$ & .47 & $-3,300$ & .15 & 2.0 \\
4 & 100 & $1 \times 10^{-6}$ & .42 & -150 & & .15 \\
\hline
\end{tabular}



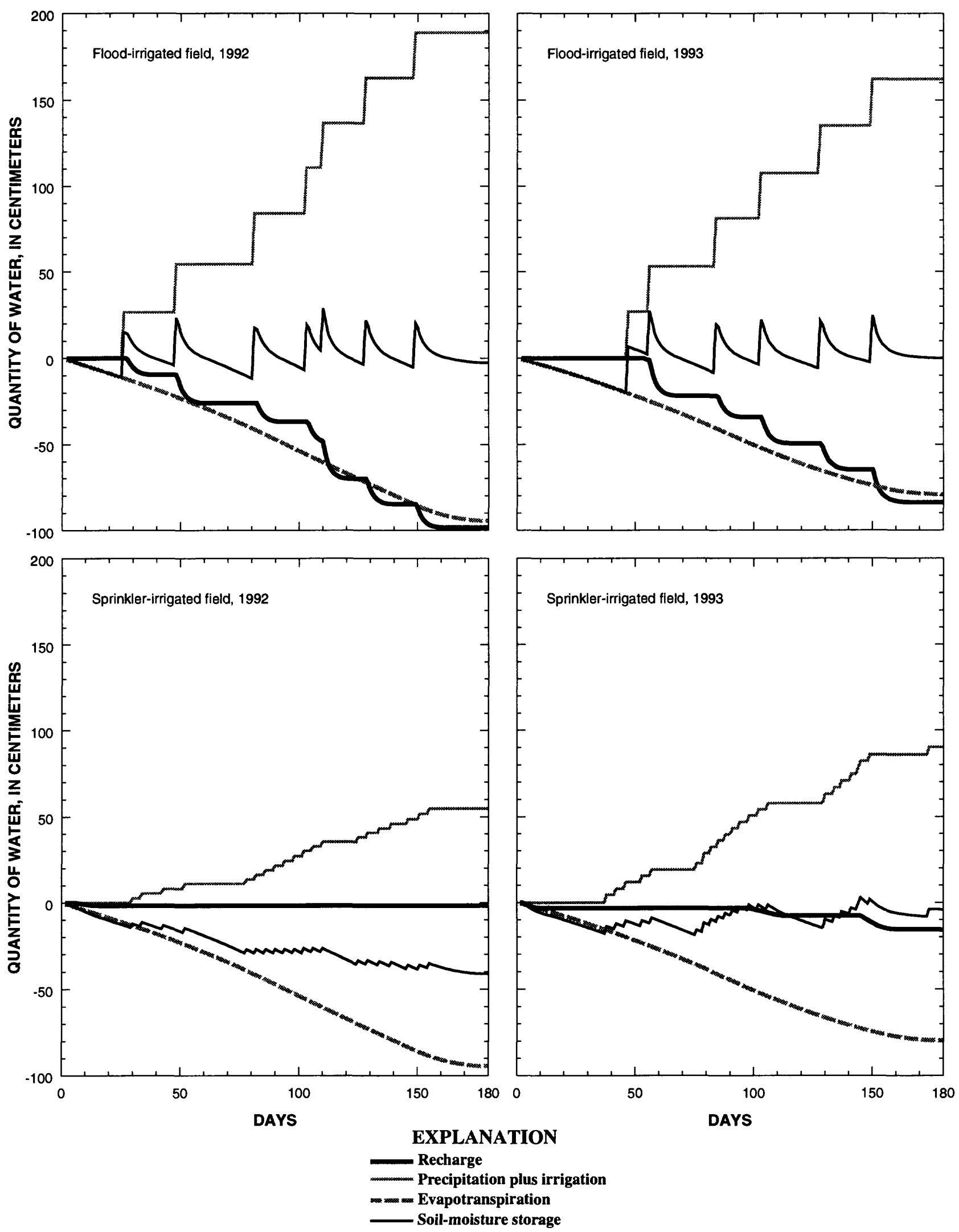

Figure 14. Simulated cumulative water budget for the flood- and the sprinkler-irrigated field for 1992 and 1993 irrigation seasons, Milford area, Utah. 
Table 2. Summary of estimated and simulated water budget for the flood- and the sprinkler-irrigated field for the 1992 and 1993 irrigation seasons, Milford area, Utah

\begin{tabular}{|c|c|c|c|c|c|c|c|c|}
\hline \multirow[t]{2}{*}{$\begin{array}{l}\text { Field and } \\
\text { year }\end{array}$} & \multicolumn{2}{|c|}{$\begin{array}{l}\text { Evapotran- } \\
\text { spiration } \\
\text { (centimeters) }\end{array}$} & \multicolumn{2}{|c|}{$\begin{array}{l}\text { Irrigation plus } \\
\text { precipitation } \\
\text { (centimeters) }\end{array}$} & \multicolumn{2}{|c|}{$\begin{array}{c}\text { Recharge } \\
\text { (centimeters) }\end{array}$} & \multicolumn{2}{|c|}{$\begin{array}{l}\text { Change in soil- } \\
\text { moisture storage } \\
\text { (centimeters) }\end{array}$} \\
\hline & Estimated & Simulated & Estimated & Simulated & Estimated & Simulated & Estimated & Simulated \\
\hline Flood, 1992 & 95.4 & 94.5 & 188.7 & 188.8 & 93.3 & 98.3 & 0 & -2.6 \\
\hline Flood, 1993 & 84.3 & 79.3 & 162.4 & 162.1 & 78 & 83.9 & 0 & .04 \\
\hline Sprinkler, 1992 & 95.4 & 94.3 & 59.5 & 54.7 & -35.9 & -1.7 & 0 & -41.1 \\
\hline Sprinkler, 1993 & 84.3 & 79.6 & 93.6 & 90.2 & 9.3 & 16.3 & 0 & -4.3 \\
\hline
\end{tabular}

ration between the estimated field water budget and the simulations is a result of rounding during the simulation and monthly averaging.

\section{Simulated Water Budget for the Flood- and the Sprinkler-Irrigated Field for Average Climate Conditions}

The water budget for the flood- and the sprinklerirrigated fields was simulated with the model for average climate conditions to compare the quantity of recharge to the aquifer from the different irrigation methods. The model calibrated to the 1992 and 1993 irrigation seasons was used for the simulation. Average net irrigation requirements for alfalfa for 1961-90 for the Milford area were used for the evapotranspiration values in the model. The average net irrigation requirements were calculated by Hill and others (1993) (R.W. Hill, Utah State University, written commun., 1994) using the calibrated Blaney Criddle equation of the Soil Conservation Service. The average net irrigation requirement is growing-season evapotranspiration minus effective precipitation. The Blaney Criddle equation was calibrated using 5 years of data from an agricultural micrometeorology station, with evapotranspiration calculated using the Kimberly version of the Penman equation (Hill and others, 1993). The 30- year average monthly net irrigation requirements (1961-90) for alfalfa in the Milford area (R.W. Hill, Utah State University, written commun., 1994), assuming that 80 percent of precipitation during the growing season is effective, are listed at the bottom of the page.

Precipitation was subtracted from model input because it is accounted for in the net irrigation requirements. Applications of irrigation water for the 1992 and 1993 irrigation seasons were used in the simulations to produce a range of irrigation applications. The seven applications to the flood-irrigated field in 1992 were more than the normal six applications for the Milford area. There were six applications in 1993. The application to the sprinkler-irrigated field in 1992 was less than crop water requirements because of the amount of water applied with each rotation and because of mechanical problems with the sprinkler system. The sprinkler-irrigated field received more frequent and larger quantities of water in 1993, with sufficient water applied to meet crop water requirements.

The simulated water-budget components for average climate conditions (fig. 15) are listed in table 3. The simulated water budgets in table 3 for each year do not balance exactly because of numerical approximation and rounding. Recharge from the flood-irrigated field in 1992 is 57.4 percent of the applied irrigation water. In 1992, there were seven irrigation applications,

\begin{tabular}{lccccccc}
\hline & April & May & June & July & August & September & Annual \\
\hline $\begin{array}{l}\text { Net irrigation } \\
\text { requirement } \\
\text { (in centimeters) }\end{array}$ & 2.31 & 15.92 & 15.19 & 20.62 & 16.18 & 9.86 & 80.08 \\
\hline
\end{tabular}


Table 3. Simulated water budget for the flood- and the sprinkler-irrigated field for average climate conditions, Milford area, Utah

\begin{tabular}{|c|c|c|c|c|c|c|}
\hline $\begin{array}{c}\text { Field and } \\
\text { year }\end{array}$ & $\begin{array}{l}\text { Evapotranspiration } \\
\text { (centimeters) }\end{array}$ & $\begin{array}{c}\text { Irrigation } \\
\text { (centimeters) }\end{array}$ & $\begin{array}{c}\text { Recharge } \\
\text { (centimeters) }\end{array}$ & $\begin{array}{l}\text { Change in soil } \\
\text { moisture in storage } \\
\text { (centimeters) }\end{array}$ & $\begin{array}{c}\text { Runoff } \\
\text { (centimeters) }\end{array}$ & $\begin{array}{l}\text { rrigation water } \\
\text { that is } \\
\text { recharge } \\
\text { (percent) }\end{array}$ \\
\hline Flood, 1992 & 78.8 & 182.0 & 104.2 & 0.15 & 0 & 57.4 \\
\hline Flood, 1993 & 78.9 & 156.0 & 78.8 & .34 & 0 & 50.5 \\
\hline Sprinkler, 1992 & 78.8 & 52.8 & 4.5 & -30.2 & 0 & 8.7 \\
\hline Sprinkler, 1993 & 78.8 & 87.2 & 14.2 & -4.4 & 0 & 13.8 \\
\hline
\end{tabular}

of which two were in a 1-week period, thereby increasing recharge. In 1993 there were six irrigation applications, which is normal for the Milford area, and 50.5 percent of the applied irrigation water became recharge. The irrigation water applied to the sprinkler-irrigated field in 1992 was less than crop water requirements, but 8.7 percent of the applied irrigation water in the simulation became recharge. This recharge is the result of drainage from the soil profile because of the initial soilmoisture profile for the soil column. This drainage from the initial soil-moisture profile might be similar to drainage that might occur from infiltration of snowmelt through the soil in the spring. In 1993 the sprinkler-irrigated field received $87.2 \mathrm{~cm}$ (34.3 in.) of irrigation water, of which 13.8 percent became recharge. Part of the 1993 recharge, $8.7 \mathrm{~cm}$ (3.4 in.), can be attributed to drainage from the initial soil-moisture profile. Actual recharge in 1993 was $5.1 \mathrm{~cm}$ (2.0 in.).

\section{Effects of Distribution of Flood-Irrigation Water on Recharge}

The distribution of irrigation water across a flood-irrigated field is nonuniform, with the upper end of the field receiving more irrigation water than the lower end. The estimated water budget and the model simulations assume a uniform distribution of water across the field. Simulation of unsaturated flow for the flood-irrigated field for 1993 was used to investigate the effects of water distribution on recharge from the field. The model was used to simulate the water budget for a uniform distribution and for a linear distribution of water on the field. The amount of water applied to the field was equal in both simulations, and there was no runoff from the fields.

The simulated uniform and linear distributions of water across the field and the evapotranspiration and recharge for each distribution are shown in figure 16. Simulations were done along the length of the field and extended for a width of 1 meter. The quantity of water applied to the fields, evapotranspiration, and recharge from the fields are:

\begin{tabular}{lcccc}
\hline $\begin{array}{c}\text { Water } \\
\text { distri- } \\
\text { bution }\end{array}$ & $\begin{array}{c}\text { Applied } \\
\text { irrigation } \\
\text { water } \\
\text { (cubic } \\
\text { meters) }\end{array}$ & $\begin{array}{c}\text { Evapotrans- } \\
\text { piration } \\
\text { (cubic } \\
\text { meters) }\end{array}$ & $\begin{array}{c}\text { Re- } \\
\text { charge } \\
\text { (cubic } \\
\text { meters) }\end{array}$ & $\begin{array}{c}\text { Applied } \\
\text { water } \\
\text { that is } \\
\text { recharge } \\
\text { (percent) }\end{array}$ \\
\hline Uniform & 600 & 304 & 296 & 49 \\
Linear & 600 & 262 & 338 & 56 \\
\hline
\end{tabular}

For the linear distribution, the lower end of the field does not have sufficient water to meet the water demands of plants; therefore, simulated evapotranspiration is less than in the uniform distribution. When water is uniformly distributed across the field, 49 percent of the irrigation water becomes recharge. For the linear distribution, 56 percent of the irrigation water becomes recharge. The assumption of a uniform distribution of water across the field underestimates recharge from irrigation by 7 percent for the simulation, and the underestimation would likely increase as evapotranspiration increases.

\section{Sensitivity Analysis}

Saturated hydraulic conductivity is an important parameter that controls flow through the unsaturated zone. Saturated hydraulic-conductivity changes between soil layers can cause ponding on layers, generate surface runoff, and force water to flow horizontally rather than vertically. The water budget determined from three selected model simulations used in the model calibration is shown in table 4 . These simula- 

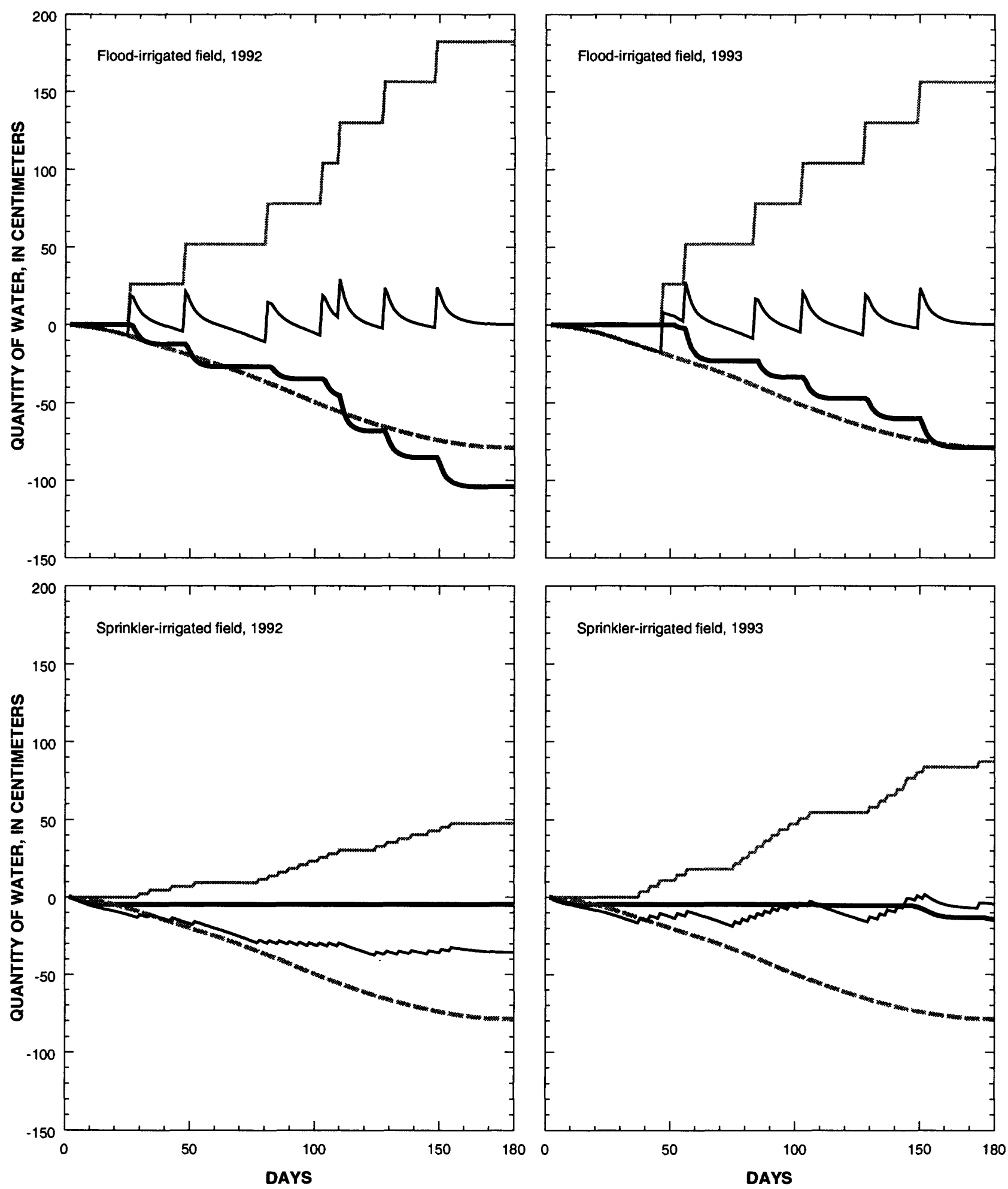

\section{EXPLANATION}

Recharge

- Precipitation plus irrigation

-m. Evapotranspiration

Soil-moisture storage

Figure 15. Simulated cumulative water budget for the flood- and the sprinkler-irrigated field for average climate conditions (1961-90) with 1992 and 1993 irrigation applications, Milford area, Utah. 
a. Uniform distribution of 1.56 meters of water across field Quantity of irrigation water applied, 600 square meters Recharge, 296 square meters 49 percent of applied water becomes recharge

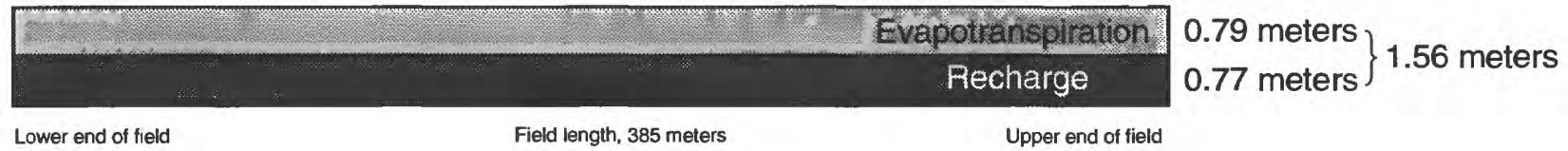

b. Linear distribution of water across field is 3.12 meters at top of field, 0 meters at bottom of field Quantity of irrigation water applied, 600 square meters Recharge, 338 square meters

56 percent of applied water becomes recharge

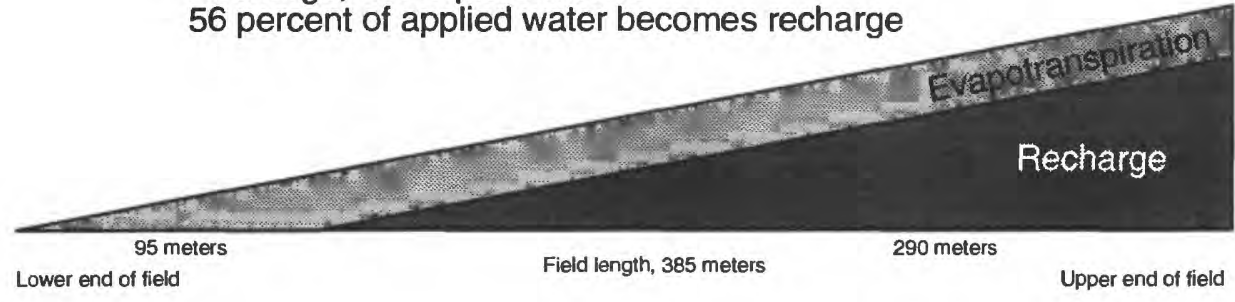

0.79 meters 2.33 meters 3.12 meters

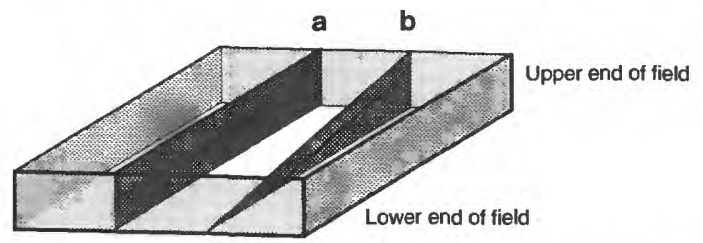

Figure 16. Simulated (a) uniform and (b) linear distribution of flood-irrigation water across a field.

tions show the effect of changes in saturated hydraulic conductivity on the water budgets. Simulation 1 used laboratory values of saturated hydraulic conductivity, except for textural class 1 , in which the saturated hydraulic-conductivity value was increased from 6.9 $\mathrm{cm} /$ day to $14 \mathrm{~cm} /$ day $(0.23$ to $0.46 \mathrm{ft} /$ day $)$. This increase was necessary to reduce the quantity of surface runoff from the field. In simulation 2 , the hydraulic-conductivity values were increased from the laboratory values by a factor of 2 for each textural class. Simulation 3 is the calibrated model, which uses saturated hydraulic-conductivity values that are increased from the laboratory values by a factor of 10 .

In simulation 1, runoff is generated from the flood-irrigated field even after doubling the saturated hydraulic conductivity because the applied irrigation water does not all infiltrate and is not accounted for by evapotranspiration, soil moisture in storage, and recharge. The percentage of precipitation and irrigation that infiltrates as recharge in the flood-irrigated field of about 50 percent in simulations 2 and 3 indicates that saturated hydraulic conductivity does not limit recharge in these simulations. However, the distribution of soil moisture is different between simulations 2 and 3 . The soil-moisture profiles from the two simulations show that water ponds over layers with low hydraulic-conductivity values. This ponding, if near the root zone, can make more water available to plants, thereby increasing evapotranspiration and reducing recharge. This simulation demonstrates the importance of not only determining the water budget but also of monitoring the distribution of soil moisture in the soil profile.

There was no recharge in the sprinkler-irrigated field in 1992 in any of the simulations. The sprinklerirrigated field received more irrigation water in 1993 than in 1992 and evapotranspiration was less because of climate conditions; therefore, recharge occurred in all three 1993 simulations. If evapotranspiration in 1993 had been equal to that in 1992, there would have been recharge only in simulation 3. 
Table 4. Water budget for three simulations that demonstrate the sensitivity of the model of the flood-and the sprinklerirrigated field to changes in saturated hydraulic conductivity, Milford area, Utah

[-, evapotranspiration is greater than precipitation plus irrigation, thus no recharge occurs and no water is added to soil-moisture storage ]

\begin{tabular}{|c|c|c|c|c|c|c|c|}
\hline $\begin{array}{l}\text { Field } \\
\text { and } \\
\text { year }\end{array}$ & $\begin{array}{c}\text { Irrigation } \\
\text { plus } \\
\text { precipitation } \\
\text { minus runoff } \\
\text { (centimeters) }\end{array}$ & $\begin{array}{l}\text { Evapotran- } \\
\text { spiration } \\
\text { (centimeters) }\end{array}$ & $\begin{array}{c}\text { Change } \\
\text { in soil } \\
\text { moisture } \\
\text { in storage } \\
\text { (centimeters) }\end{array}$ & $\begin{array}{c}\text { Recharge } \\
\text { (centimeters) }\end{array}$ & $\begin{array}{l}\text { Fraction of } \\
\text { irrigation } \\
\text { plus precipitation } \\
\text { minus runoff } \\
\text { consumed by } \\
\text { evapotranspiration } \\
\text { (percent) }\end{array}$ & $\begin{array}{c}\text { Fraction of } \\
\text { irrigation } \\
\text { plus precipitation } \\
\text { minus runoff } \\
\text { that is } \\
\text { recharge } \\
\text { (percent) }\end{array}$ & $\begin{array}{l}\text { Fraction of } \\
\text { irrigation plus } \\
\text { precipitation } \\
\text { minus runoff } \\
\text { that is change } \\
\text { in storage } \\
\text { (percent) }\end{array}$ \\
\hline
\end{tabular}

\begin{tabular}{|c|c|c|c|c|c|c|c|}
\hline \multicolumn{8}{|c|}{ Simulation 1} \\
\hline Flood, 1992 & 182.4 & 94.8 & 6.1 & 74.8 & 52 & 40 & 3.3 \\
\hline Flood, 1993 & 150.1 & 79.5 & 9.1 & 61.7 & 53 & 41 & 6 \\
\hline Sprinkler, 1992 & 54.7 & 94.5 & -39.8 & 0 & 100 & - & - \\
\hline Sprinkler, 1993 & 90.2 & 79.6 & 3.3 & 7.4 & 88 & 8 & 4 \\
\hline \multicolumn{8}{|c|}{ Simulation 2} \\
\hline Flood, 1992 & 188.9 & 94.5 & -.77 & 95.5 & 50 & 51 & 0 \\
\hline Flood, 1993 & 160.1 & 79.4 & 1.2 & 80.1 & 50 & 50 & 1 \\
\hline Sprinkler, 1992 & 54.7 & 94.4 & -41.1 & -1.7 & 100 & - & - \\
\hline Sprinkler, 1993 & 90.2 & 79.6 & -3.1 & 14.2 & 88 & 15 & -3 \\
\hline \multicolumn{8}{|c|}{ Simulation 3} \\
\hline Flood, 1992 & 188.8 & 94.5 & -2.6 & 98.3 & 50 & 52 & -1 \\
\hline Flood, 1993 & 162.1 & 79.3 & .04 & 83.9 & 49 & 51 & 0 \\
\hline Sprinkler, 1992 & 54.7 & 94.3 & -41.1 & -1.7 & 100 & - & - \\
\hline Sprinkler, 1993 & 90.2 & 79.6 & -4.3 & 16.0 & 88 & 17 & -5 \\
\hline
\end{tabular}

\section{Limitations of the Model}

The model simulates vertical one-dimensional flow through the upper $6.4 \mathrm{~m}(21 \mathrm{ft})$ of the unsaturated zone at the field site. Model solutions are nonunique because different combinations of parameters can produce the same result. Because evapotranspiration accounts for about 50 percent of the water budget, errors in the estimation of evapotranspiration could cause large errors in the water budget. The model does not account for any horizontal flow, nor does it account for the fate of water once it infiltrates below $6.4 \mathrm{~m} \mathrm{(21}$ $\mathrm{ft}$ ). The model was discretized and calibrated to a specific soil profile. The simulations allow comparison of probable recharge for soil profiles with similar hydraulic properties and allow comparison of probable recharge resulting from the use of different irrigation methods. The simulations use estimates of evapotranspiration from field data, and the uncertainty in these estimates is carried over to the simulation results.

\section{Summary}

Irrigators in the western United States are converting from less efficient irrigation methods, such as flood irrigation, to more efficient sprinkler systems. In theory, ground-water withdrawals for irrigation decrease as irrigation efficiency improves; however, many irrigators are increasing irrigated acreage as they improve irrigation efficiency. Ground-water withdrawals are thereby maintained and may reduce recharge from unconsumed irrigation water and contribute to ground-water-level declines. A cooperative study between the U.S. Geological Survey and the Utah Department of Natural Resources, Division of Water Rights, was initiated to quantify and compare the quantity of ground-water recharge from irrigation water using flood- and sprinkler-irrigation methods.

The study site is in the Milford area of southwestern Utah and consists of two adjacent irrigated alfalfa fields; a flood-irrigated field and a center-pivot sprinkler-irrigated field. The soils at the study site are generally classified as loam to clay loam. Soil samples from 
pits and cores from selected intervals were collected. The particle-size distribution indicates that the texture of the unsaturated zone is heterogeneous and layered.

The study site was instrumented to measure soil moisture and climate parameters. Soil moisture was measured with a soil-moisture neutron probe at two locations in the flood-irrigated field and two locations in the sprinkler-irrigated field. Soil-moisture measurements were made at about 2-week intervals in 1992 and daily for May and part of June in 1993. Climate parameters were measured with an automated weather station sited between the flood- and the sprinkler-irrigated field. Measurements were not made in the fields.

The components of the water budget for each field were measured at intervals, or calculated or estimated at the study site. Precipitation at the study site during April to September was about $6.5 \mathrm{~cm}$ (2.6 in.) in 1992 and 1993. The farmers recorded application dates of irrigation water to the flood- and the sprinkler-irrigated field. The flood-irrigated field received about 182 $\mathrm{cm}$ (71.6 in.) of water in 1992 and $156 \mathrm{~cm}$ (61.4 in.) in 1993. The sprinkler-irrigated field was irrigated using a center-pivot sprinkler system that revolved every 3 to 4 days. The sprinkler applied 2.6 to $3.8 \mathrm{~cm}$ (1.0 to $1.5 \mathrm{in}$.) of water per revolution. The sprinkler-irrigated field received about $52.8 \mathrm{~cm}$ (20.8 in.) of water in 1992 and $87.2 \mathrm{~cm}$ (34.3 in.) in 1993.

Evapotranspiration was calculated using the Penman-Monteith combination equation. Daily evapotranspiration ranged from 1.2 to $13.4 \mathrm{~mm} /$ day $(0.0039$ to $0.044 \mathrm{ft} /$ day) in 1992 and from 2.5 to $14.4 \mathrm{~mm} /$ day ( 0.0082 to $0.047 \mathrm{ft} /$ day) in 1993. Cumulative evapotranspiration was $95.4 \mathrm{~cm}$ (37.6 in.) for April 1 to September 15, 1992, and $84.3 \mathrm{~cm}$ (33.2 in.) for April 1 to September 30, 1993. Evapotranspiration was estimated for both the flood-and the sprinkler-irrigated field from a single set of climate data that was collected between the two fields. This climate data represents an average data set for the area because the site was surrounded by irrigated alfalfa fields, thus, evapotranspiration calculated from it may differ from evapotranspiration actually measured in the fields. No runoff was observed from either the flood- or the sprinkler-irrigated field.

Soil moisture was measured about every 2 weeks in 1992 and daily in May and part of June of 1993. The soil moisture varied plus or minus 5 percent and did not change substantially from the beginning to the end of the irrigation season; thus, for the water budget, no change in the quantity of soil moisture in storage is assumed. The lower end of the flood-irrigated field was an exception. The quantity of irrigation water was insufficient to satisfy plant water requirements at the lower end of the field, and the entire soil profile dried out.

Estimated recharge for the flood-irrigated field in 1992 was $93.3 \mathrm{~cm}$ (36.7 in.) and in 1993 was $78.1 \mathrm{~cm}$ (30.7 in.). The estimated recharge is 49 percent and 48 percent, respectively, of the sum of precipitation and irrigation during April to September in 1992 and 1993. Estimated recharge in the sprinkler-irrigated field in 1992 was $-35.9 \mathrm{~cm}(-14.1$ in.) and in 1993 was $9.3 \mathrm{~cm}$ (3.7 in.).

An unsaturated-flow model was used to simulate vertical infiltration through the upper $6.4 \mathrm{~m}(21 \mathrm{ft})$ of the unsaturated zone. Water that infiltrated to a depth of

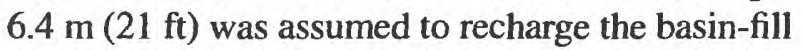
aquifer. The model was constructed and calibrated using measured and estimated water-budget components and soil-moisture profiles from the flood-and the sprinkler-irrigated field. A composite soil column was created for the model from data from both fields that includes four textural classes and five layers. Initial soil properties and derived parameters required by the model were laboratory determined or were calculated from laboratory-determined values.

Model calibration required adjustment of the saturated hydraulic-conductivity values and the van Genuchten equation parameters to prevent surface runoff, ponding on soil layers, and large variations in soil moisture. Saturated hydraulic-conductivity values were increased by an order of magnitude, and the van Genuchten $-\alpha$ ' was decreased in two of the textural classes. Simulations with the calibrated model-computed water-budget components are generally within $5 \mathrm{~cm}$ of the estimated water budget. The variations in simulated soil moisture are less than 20 percent, with most of the variation in the soil-moisture profiles in the 10-percent range.

The water budget for the flood- and the sprinklerirrigated field was simulated with the model for average climate conditions to compare recharge to the aquifer by means of each irrigation method. Recharge from the flood-irrigated field in 1992 is 57.4 percent of the applied irrigation water. In 1992, there were seven irrigation applications, of which two were in a 1-week period, thereby increasing recharge. In 1993 there were six irrigation applications, which is normal for the Milford area, and 50.5 percent of the applied irrigation water became recharge. The irrigation water applied to the sprinkler-irrigated field in 1992 was less than crop 
water requirements, but 8.7 percent of the applied irrigation water in the simulation became recharge. This recharge is the result of drainage from the soil profile because of the initial soil-moisture profile for the soil column. This drainage from the initial soil-moisture profile might be similar to drainage that might occur from infiltration of snowmelt through the soil in the spring. In 1993 the sprinkler-irrigated field received $87.2 \mathrm{~cm}$ (34.3 in.) of irrigation water, of which 13.8 percent became recharge.

The one-dimensional model was used to simulate the water budget for a uniform distribution and for a linear distribution of water on the field. In these simulations, 49 percent of the irrigation water from the uniform distribution became recharge and 56 percent of the irrigation water from the linear distribution became recharge. If evapotranspiration increases, then the percentage of irrigation water that is recharge would increase for the linear distribution relative to the uniform distribution.

\section{REFERENCES CITED}

Allen, R.G., Jensen, M.E., Wright, J.L., and Burman, R.D., 1989, Operation estimates of reference evapotranspiration: Agronomy Journal, v. 81, no. 4 , p. $650-662$.

Bowman, R.S., Stephens, D.B., Arnet, P., Grabaka, D.P., Schmidt-Peterson, R.I., and Stark, A.M., 1991, Field study of multidimensional flow and transport in the vadose zone, WRRI Report No. 262, New Mexico Water Resources Research Institute, p. 132.

Campell, G.S., 1977, An introduction to environmental biophysics: New York, Springer-Verlag, 159 p.

Fenneman, N.M., 1931, Physiography of the western United States: New York, McGraw-Hill, 534 p.

Healy, R.W., 1990, Simulation of solute transport in variably saturated porous media with supplemental information on modifications to the U.S. Geological Survey's computer program VS2D: U.S. Geological Survey Water-Resources Investigations Report 90-4025, 125 p.

Hill, R.W., Austin, L., Olds, J. and Stauffer, N., 1993, Updating Utah's crop water use estimates, in Allen, R.G., and Neale, C.M., eds., Management of Irrigation and Drainage Systems: Integrated Perspectives, Proceedings of the 1993 National Conference on Irrigation and Drainage Engineer- ing, Park City, Utah: New York, American Society of Civil Engineers, p. 1015-1022.

Klusman, R.W., 1980, Sampling designs for geochemical baseline studies in the Colorado oil shale region: a manual for practical application: U.S. Department of Energy, DOE/EV/10298-2, 180 p.

Kramer, J.H., Cullen, S.J., and Everett, L.G., 1992, Vadose zone monitoring with the neutron moisture probe: Ground Water Monitoring Review, v. XII, no. 3 , p. $177-187$.

Lappala, E.G., Healy, R.W., and Weeks, E.P., 1983, Documentation of computer program VS2D to solve the equation of fluid flow in a variably saturated porous media: U.S. Geological Survey Water-Resources Investigations Report 83-4099, $184 \mathrm{p}$.

Lowe, P. R., 1977, An approximating polynomial for the computation of saturation vapor pressure: Journal of Applied Meteorology, 16, p. 100.

Monteith, J. L., 1963, Gas exchange in plant communities, in L.T. Evans, ed., Environmental Control of Plant Growth: New York, Academic Press, p. 205234.

Mower, R.W., and Cordova, R.M., 1974, Water resources of the Milford area, Utah, with emphasis on ground water: Utah Department of Natural Resources Technical Publication No. 43, 106 p.

Penman, H.L., 1956, Estimating evaporation: American Geophysical Union Transactions, v. 37, no. 1, p. 43-50.

Rawls, W.J., Brakensiek, D.L., and Saxton, K.E., 1982, Estimation of soil water properties: Transactions of the American Society of Agricultural Engineers, v. 25, p. $1316-1320$.

Tomlinson, S.A., 1994, Instrumentation, methods, and preliminary evaluation of evapotranspiration for a grassland in the Arid Lands Ecology Reserve, Benton County, Washington, May-October 1990: U.S. Geological Survey Water-Resources Investigations Report 93-4081, 32 p.

Van Bavel, C. H. M., 1967, Changes in canopy resistance to water loss from alfalfa induced by soil water depletion: Agricultural Meteorology, 4, p. 165-176.

van Genuchten, M. Th., 1980, A closed-form equation for predicting the hydraulic conductivity of unsaturated soils: Soil Science Society of America Proceedings, v. 44 , no. 5 , p. $892-898$.

Weiss, A., 1983, A quantitative approach to the Pruitt and Doorenbos version of the Penman equation: Irrigation Science, v. 4, p. 267-275. 